\title{
THE ROLE OF THE COURT IN BALANCING CONTRACTUAL FREEDOM WITH THE NEED FOR MANDATORY CONSTRAINTS ON OPPORTUNISTIC AND ABUSIVE CONDUCT IN THE LLC
}

\author{
SANDRA K. MILLER ${ }^{\dagger}$
}

\begin{abstract}
Courts are establishing a mandatory core of acceptable business conduct within the relatively new context of the limited liability company (LLC). Outside of Delaware, courts have tailored traditional notions of corporate and/or partnership fiduciary duties to the LLC, while within Delaware, courts are developing minimum standards of conduct through restricted interpretations of contractual waivers, rigorous application of the entire fairness standard, and recourse to contractually based concepts of good faith. This Article suggests that a broad and traditional approach to fiduciary duties is preferable to a narrower analysis of entire faimess or contractually oriented good faith because a broader formulation better reflects society's norms of ethical conduct, more adequately serves all sectors of the private business community, may be more effective in combating subtle freezeout schemes, and does not presume that the parties' relationship is governed by a highly negotiated contract. Furthermore, this Article emphasizes that courts are central to all LLC modeling, including Delaware's contractarian paradigm, and are leading the way toward the development of a mandatory frame of reference for balancing the interest in contractual freedom with the need for minimum standards to curb opportunistic and abusive conduct.
\end{abstract}

\section{INTRODUCTION}

The limited liability company (LLC) has been hailed as the entity of choice in the privately owned business arena. Freed from mandatory tax classification rules, the LLC, in addition to limiting liability, can now possess the corporate characteristic of "continuity of life" and need not dissolve when a member withdraws, dies, or becomes bankrupt.' Private entrepreneurs have an unparalleled range of choices

${ }^{\dagger}$ Associate Professor, Widener University School of Business Administration. I would like to thank Dean and Professor Donald J. Weidner, Florida State University College of Law, as well as Professors Barbara Ann Banoff, James Rossi, Mark Seidenfeld, and the other faculty members at Florida State University College of Law, who offered helpful comments when I presented an outline of this Article at Florida State University College of Law earlier this year. I am grateful to Elizabeth Stone Miller for reading a draft of this Article and would like to give special thanks to Kenneth Miller for his many insights and editorial suggestions.

See Classification of Certain Business Entities 26 C.F.R. $\$ 301.7701-3$ (2001) (permitting the LLC to elect its classification for federal tax purposes); Laurel Wheeling Farrar \& Susan Pace Hamill, Dissociation from Alabama Limited Liability Companies in the 
for structuring LLC relationships, and LLC participants have access to the twin benefits of corporate limited liability and flow-through partnership tax status.

Two major forces contributed to the development of the LLC. First, practitioners sought the flexibility to structure their clients' internal relationships while continuing to receive favorable flow-through tax treatment. ${ }^{2}$ Second, in an atmosphere of escalating jury awards, ${ }^{3}$ practitioners advocated control over the legal liability of their clients with respect to both coinvestors and third parties. ${ }^{4}$ They wanted a framework that would reduce judicial encroachment into the business deals that they negotiated and formalized. ${ }^{5}$

Each state, as well as the District of Columbia, now has its own LLC statute, ${ }^{6}$ and these statutes allow a great deal of freedom in forming an LLC. ${ }^{7}$ The statutes typically assume that the individual owners

Post Check-the-Box Era, 49 ALA. L. REV. 909, 912-13 (1998) (highlighting the increased flexibility afforded by the Internal Revenue Service to structure LLCs like corporations with continuity of life and remarking on an amendment in Alabama's LLC statute that eliminates the possibility of dissolution or dissociation even if members die or leave the LLC); see also Conrad S. Ciccotello \& C. Terry Grant, LLCs and LLPs: Organizing to Deliver Professional Services, BUS. HORIZONS, Mar.-Apr. 1999, at 85, 85 ("Nearly 25 times as many new LLC registrations occurred in 1996 as in 1992.”). See generally Thomas M. Hayes, Note, Checkmate, the Treasury Finally Surrenders: The Check-the-Box Treasury Regulations and Their Effect on Entity Classification, 54 WASH. \& LEE L. REV. 1147, 1160-68 (1997) (detailing the changes to the tax entity classification rules).

${ }^{2}$ See Susan Pace Hamill, The Limited Liability Company: A Catalyst Exposing the Corporate Integration Question, 95 MiCH. L. REV. 393, 394-96 (1996) (discussing the LLC's partnership-style benefits of pass-through taxation and limited liability and noting concerns that the LLC could pose a serious challenge to the double taxation regime, which taxes corporate profits both when the corporation earns them and when they are distributed to the shareholders).

${ }^{3}$ See Liability Awards Are on the Rise, CORP. LEG. TIMES, June 2000, at 22, 22 (indicating that national jury awards in most liability suits have risen significantly).

See Dale A. Oesterle, Subcurrents in LLC Statutes: Limiting the Discretion of State Courts to Restructure the Internal Affairs of Small Business, 66 U. COLO. L. REV. 881, 881 (1995) (discerning a movement among some tort reformers to expand the role of the LLC as a potential solution to excessive liability); cf. James A. Henderson, Jr., The Boundary Problems of Enterprise Liability, 41 MD. L. REv. 659, 662-76 (1982) (suggesting a list of liability triggers to provide increased certainty in the law).

${ }^{5}$ See Oesterle, supra note 4, at 883 (observing that state legislatures' push to "relax judicial supervision of small businesses" was a leading factor in the rise of the LLC); see also Donald J. Weidner, Three Policy Decisions Animate Revision of Uniform Partnership Act, 46 Bus. LAw. 427, 428 (1991) (articulating practitioners' concern with certainty of the law and their fear that their clients' contractually negotiated business deals could be undone by "fuzzy" notions of fiduciary duty).

${ }^{6}$ Infra Appendix A.

7 See Ann E. Conaway Stilson, The Agile Virtual Corporation, 22 DEL. J. CORP. L. 497,518 (1997) (recognizing that "the present trend in LLC . . legislation reflects an 
will develop their own LLC operating agreements that define their respective rights, responsibilities, and remedies. Often described as enabling legislation, the LLC statutes largely provide a series of default rules that apply in the absence of contractual provisions to the contrary. ${ }^{8}$ While some LLC statutes contain express mandatory fiduciary duties, ${ }^{9}$ others, particularly the Delaware LLC statute, do not. ${ }^{10}$ Delaware's contractarian vision of business entities is evidenced in its policy to give the maximum effect to the principles of freedom of contract and strict enforcement of LLC agreements. ${ }^{11}$

Now that over a decade has elapsed since the first LLCs were formed, it is an opportune time to evaluate the LLC experiment. How successful has enabling legislation been in reducing disputes among business associates? Has there been a reduction in the need for judicial intervention? Is Delaware's contractarian model leading to fewer lawsuits and increased freedom from judicial monitoring? The short answer to these questions is "no."12

This Article compares the developing case law on fiduciary duties both outside and inside Delaware and finds that across the board,

attitude favoring maximum freedom of contract among LLC . . participants"). See generally CARTER G. BISHOP \& DANIEL S. KLEINBERGER, LIMITED LIABILITY COMPANIES (1996) (offering a comprehensive treatise on LLCs nationwide); LARRY E. RIBSTEIN \& ROBERT R. KEATINGE, RIBSTEIN AND KEATINGE ON LIMITED LIABILITY COMPANIES (2002) (rendering a detailed analysis of LLCs and containing indices that categorize the manner in which states approach various issues of operation from formation to dissolution).

${ }^{8}$ See Larry E. Ribstein, The Deregulation of Limited Liability and the Death of Partnership, 70 WASH. U. L.Q. 417, 425-38 (1992) (providing insight into the history of the LLC and its goal of offering partnership-like flexibility through the primacy of the LLC operating agreement).

${ }^{9}$ See, e.g., CAL. CORP. CODE $\S 17,153$ (West Supp. 2004) (indicating that the fiduciary duties a manager owes to the LLC and its members are those of a partner to a partnership and to the partners of the partnership); FLA. STAT. ANN. $\$ 608.4225$ (West 2001 \& Supp. 2004) (outlining the duties of loyalty and care); N.Y. LTD. LIAB. Co. LAW $\$ 409$ (McKinney 2004) (mandating that a manager perform her duties "in good faith and with that degree of care that an ordinarily prudent person in a like position would use under similar circumstances"); 15 PA. CONS. STAT. ANN. $\$$ 8943(b) (West 1995 \& Supp. 2003) (adopting a corporate standard of care for LLCs with managers).

${ }^{10}$ See DEL. CODE ANN. tit. 6., $\$ 18-1101$ (b) (1999) (deferring to the freedom of contract).

${ }^{11} I d$.

${ }^{12}$ See Jack B. Jacobs, Entity Rationalization: A Judge's Perspective, 58 Bus. LAW. 1043, 1044-46 (2003) (discussing the astonishingly large volume of litigation created by alternative entity forms, including LLCs, in Delaware); Sandra K. Miller, A New Direction for LLC Research in a Contractarian Legal Environment, 76 S. CAL. L. REV. 351, 396 (2003) (observing a particularly high rate of litigation with majority/minority LLC disputes in Delaware). 
there is a continuing need for the imposition of judicial remedies for abusive and opportunistic conduct. Regardless of whether the LLC statutes contain express fiduciary duties or, conversely, embrace a broad mandate for contractual freedom, courts are compelled to address the enduring issue of fiduciary breaches. The LLC statutes are relatively new, but abusive conduct is not. LLC cases have arisen repeatedly in which majority-owners have removed or reduced the ownership percentages of their minority partners. ${ }^{18}$ Allegations of abusive LLC conduct have included claims that business opportunities have been stolen, ${ }^{14}$ that LLC members have been improperly excluded, ${ }^{1.5}$ and that LLC assets have been improperly transferred to another entity. ${ }^{16}$ These classic "squeeze-out techniques," which have a long history in the close corporation setting of the past fifty years, are now surfacing in the context of the LLC. ${ }^{17}$

In response to these abuses, courts are formulating a mandatory core of fiduciary duties as they mediate disputes among LLC business associates. How then can this development in the LLC case law be

${ }^{13}$ See, e.g., VGS, Inc. v. Castiel, No. 17995, 2000 Del. Ch. LEXIS 122, at *13-14 (Del. Ch. Aug. 31, 2000) (holding that two of three LLC board members breached their fiduciary duties by failing to notify a third board member of a proposed merger); see also Solar Cells, Inc. v. True N. Partners, LLC, No. 19477, 2002 Del. Ch. LEXIS 38, at *18-19 (Del. Ch. Apr. 25, 2002) (deciding that a merger should be enjoined as an unfair transaction where defendants unilaterally structured the terms that would dilute plaintiff's ownership and voting rights).

${ }^{14}$ See, e.g., Lynch Multimedia Corp. v. Carson Communications, L.L.C., 102 F. Supp. 2d 1261, 1261-62 (D. Kan. 2000) (claiming that other LLC member companies breached their fiduciary duties by independently acquiring other cable franchises).

${ }^{15}$ See, e.g., Anest v. Audino, 773 N.E.2d 202, 210 (Ill. App. Ct. 2002) (alleging that defendant breached his fiduciary duty as a fellow member of the LLC by failing to present plaintiff with the opportunity to enter into an exclusive distributorship agreement that was offered to the LLC), appeal denied, 787 N.E.2d 154 (IIl. 2002).

${ }^{16}$ See, e.g., Flippo v. CSC Assocs. III, 547 S.E.2d 216, 221-22 (Va. 2001) (affirming court's ruling that defendant breached his fiduciary duty to plaintiff by transferring assets to a new entity to achieve personal estate planning goals).

${ }^{17}$ See, e.g., Fine v. Bork, No. 010808586, 2002 Conn. Super. LEXIS 181, at *2-4 (Conn. Super. Ct. Jan. 15, 2002) (involving a unilateral amendment to an LLC operating agreement allowing the LLC to be owned by one member and a subsequent dissolution of the LLC resulting in a squeeze-out of the minority); see also Credentials Plus, LLC v. Calderone, 230 F. Supp. 2d 890, 893-94, 896-900 (N.D. Ind. 2002) (concerning a breach of fiduciary duty where the minority LLC manager quit working for the LLC and started her own company, taking the LLC's business with her). See generally 2 F. HODGE O'NEAL \& ROBERT B. THOMPSON, O'NEAL'S CLOSE CORPORATIONS $\$ 9.02$ (3d ed. Supp. 2003) (discussing the problems of dissension, oppression, and deadlock in the context of close corporations). 
reconciled with the contractarian model of the business entity? ${ }^{18}$ At first glance, this external monitoring does not appear to fit within the contractarian equation that emphasizes the supremacy of the private contract and the importance of reducing transaction costs through lack of external interference. It is suggested, though, that the contractarian model can be reconciled with the mandatory core of duties emerging in LLC case law by recognizing that at the heart of the private contract is the notion that there is a legally enforceable bargain subject to the many mandatory constraints of the legal environment. ${ }^{19}$

The primary message of this Article is that the courts are central to all LLC models, including Delaware's contractarian paradigm, and are leading the way toward balancing the interest in contractual freedom with the need to constrain opportunistic and deceptive conduct through the development of a minimum mandatory core of acceptable business conduct. This developing LLC case law illustrates that even under Delaware's contractarian approach, the LLC is not the proper vehicle for eliminating or diminishing judicial intervention; rather, the LLC is a business entity that permits private contracting within the context of mandatory restraints. The private business entity contract can be seen as operating within a framework of mandatory fiduciary duties that may be modified, but not wholly eliminated, and that are enforced through active judicial intervention.

Part I of this Article discusses the contractarian model, its manifestations in corporate, partnership, and LLC law, and its theoretical basis. Part II examines the statutory underpinnings of fiduciary duties applicable to LLC members and managers and the policy questions that are raised. Parts III and IV explore the judicial monitoring of

${ }^{18}$ See John C. Coffee, Jr., The Mandatory/Enabling Balance in Corporate Law: An Essay on the Judicial Role, 89 CoLUM. L. REv. 1618, 1618-23 (1989) (identifying the clash between the policy interest in contractual freedom and the competing interest in a mandatory core of corporate regulation). states:

${ }^{19}$ Regarding the judicial role in private agreements, Professor John C. Coffee

[A]n exclusive focus on economics ignores an important feature common to all forms of long-term relational contracts: namely that courts have invariably played an active and indispensable role in monitoring and interpreting such agreements. Indeed, the feasibility of such contracting probably depends upon the parties' ability to rely upon the courts to play such a role.

Id. at 1620-21 (footnote omitted); see also Deborah A. DeMott, Fiduciary Obligation Under Intellectual Siege: Contemporary Challenges to the Duty to Be Loyal, 30 OSGOODE HALL L.J. 471, 484 (1992) (observing that "contract law itself includes mandatory rules not subject to being trumped or ousted by the parties' agreement"). 
fiduciary duties that has occurred in LLC cases both outside and inside Delaware.

In particular, Part III observes that in spite of the broad, permissive language that exalts the primacy of the contract, a mandatory core of minimum fiduciary duties appears to be thriving in Delaware through express statements by the Delaware courts and in cases requiring a showing of fundamental fairness where the presumption of the business judgment rule has been rebutted. Also, this network of minimum standards of acceptable business conduct is supported in Delaware through the courts' resourcefulness in using contractually based principles of good faith.

Next, Part IV addresses the common ground shared by courts outside and inside Delaware and argues that across all jurisdictions, the courts are defending plaintiffs against the usual litany of evils-clandestine, fundamental changes in the business, ${ }^{20}$ unilateral transfers of assets, ${ }^{21}$ sudden meetings that dramatically reduce the plaintiff's control of the company, ${ }^{22}$ and the diversion of business opportunities to a competing entity. ${ }^{23}$ Regardless of whether the judicial safeguards are described as a partnership-style duty to account for benefits of the business, a corporate-style duty to act in good faith in the best interests of the company, or a required showing of fundamental fairness based on a conflict of interest and lack of good faith, the courts appear to be fashioning a mandatory core of acceptable business conduct in the context of the LLC.

Finally, Part V of the Article emphasizes that all LLC models, including the contractarian paradigm, should acknowledge the influence of courts in an environment of private ordering, the valuable role played by equitable principles generally, and the role fiduciary duties play in reflecting ethical norms in the business community. ${ }^{24}$

${ }^{20}$ See, e.g., Fine, 2002 Conn. Super. LEXIS 181, at *2-4 (concerning a majority shareholder that changed the terms of the LLC without the minority's knowledge or consent).

${ }^{21}$ See, e.g., Flippo, 547 S.E.2d at 219-20 (involving two of three shareholders selling their interests to a separate company in order to force a dissolution of the LLC).

${ }^{22}$ See, e.g., VGS, Inc. v. Castiel, No. 17995, 2000 Del. Ch. LEXIS 122, at *5 (Del. Ch. Aug. 31, 2000) (regarding the failure to notify a board member of a proposed merger that had the effect of divesting that member of his majority control of the business).

${ }^{23}$ See, e.g., Credentials Plus, LLC v. Calderone, 230 F. Supp. 2d 890, 899-900 (N.D. Ind. 2002) (concluding that the solicitation of a previous LLC/employer's business opportunities while retaining shares in that LLC was a breach of fiduciary duties).

${ }^{24}$ See generally Margaret M. Blair \& Lynn A. Stout, Trust, Trustworthiness, and the Behavioral Foundations of Corporate Law, 149 U. PA. L. REV. 1735, 1738-43 (2001) (noting 


\section{THE CONTRACTARIAN THEORY OF THE BUSINESS ENTITY}

LLC statutes may be characterized as enabling legislation. While LLC statutes typically contain some mandatory rules, many simply provide default rules that apply only in the absence of contrary provisions in the parties' operating agreements. ${ }^{25}$ Implicit in the structure of LLC legislation is the notion that parties will contractually fine-tune the parameters of their legal relationship in the governing documents of the business entity.

A similar situation developed earlier in the corporate context regarding directors' liability for monetary damages arising out of violations of the standard of care. Here, the concept of contractually limiting director liability manifested itself in the enactment of enabling statutes that allow shareholders to insulate directors from liability by adopting certain provisions in their articles of incorporation. ${ }^{26}$ Prompted by the decision in Smith v. Van Gorkom ${ }^{27}$-holding outside directors liable for gross negligence in approving a cash-out merger without properly informing themselves about the value of the company-the Delaware legislature led what soon became a national stampede toward allowing articles of incorporation to eliminate personal director liability for monetary damages stemming from breaches of fiduciary duties, except in specific cases, i.e., violations of the duty of loyalty, acts or omissions not in good faith, and conduct involving improper personal benefits. ${ }^{28}$

and examining the social context of trustworthy behavior and stressing the behavioral dimensions of corporate law).

${ }^{25}$ See BISHOP \& KLEINBERGER, supra note 7, I 7.02(1) (stating that "under all but one enabling statute the statutory structure is a default rule," and suggesting that, even under a mandatory regime, an LLC's operating agreement could substantially affect an LLC's management structure).

${ }^{26}$ See Douglas M. Branson, Assault on Another Citadel: Attempts to Curtail the Fiduciary Standard of Loyalty Applicable to Corporate Directors, 57 FORDHAM L. REV. 375, 381-82 (1988) (indicating that, for the most part, other states have followed Delaware's lead by permitting corporations to opt out of liability for violations by their officials); Coffee, supra note 18 , at 1619 (discussing the central role played by courts in monitoring and interpreting agreements in the corporate setting); Harvey Gelb, Director Due Care Liability: An Assessment of the New Statutes, 61 TEMP. L. Rev. 13, 28-32 (1988) (reviewing statutory efforts to alleviate director concerns about liability for due care violations).

${ }^{27} 488$ A.2d 858, 859 (Del. 1985) (directing the Delaware Chancery Court to award damages where the members of a board of directors were not entitled to the presumption that their business decision was an informed one).

${ }^{28}$ See DEL. CODE ANN. tit. 8, $\$ 102(b)(7)$ (2001); Stephen A. Radin, The Director's Duty of Care Three Years After Smith v. Van Gorkom, 39 HASTINGS L.J. 707, 744-54 (1988) (analyzing the statutory response to the Van Gorkom decision). Delaware passed the first authoritative provision that allowed the articles of incorporation to limit or even 
In the context of the noncorporate business entity, the movement toward contractually controlling liability has been reflected in the enactment of the Revised Uniform Partnership Act (RUPA) ${ }^{29}$ and the Uniform Limited Liability Company Act (ULLCA). ${ }^{30}$ While neither Act permits unlimited contractual freedom, both Acts enhance it by providing default rules that apply in the absence of an agreement to the contrary. ${ }^{31}$ In addition, many states have enacted their own LLC default rules, offering in varying degrees significant flexibility and contractual freedom in structuring business relationships. ${ }^{32}$ The

exclude corporate directors' liability for any breach of duty of care provided that the provision did not eliminate or limit the liability for a breach of loyalty, for acts or omissions not in good faith or involving intentional misconduct, or for transactions from which the director derived improper personal benefits. Branson, supra note 26 , at 380 82. Other states have for the most part followed Delaware's lead by permitting corporations to opt out of liability for violations by their officials. Id.

${ }^{29}$ See REVISED UNIF. P'SHIP ACT $\$ \S 103(\mathrm{~b})$, 404(a) (1997) (limiting partners' duties to the duty of loyalty and the duty of care, although restricting the ability of the partnership agreement to eliminate the duty of loyalty, unreasonably reduce the duty of care, or remove the obligations of good faith and fair dealing); see also Dennis $\mathrm{Hy}$ nes, Fiduciary Duties and RUPA: An Inquiry into Freedom of Contract, LAW \& CONTEMP. PROBS., Spring 1995, at 29, 34-35 (noting that the drafters of RUPA attempted to deny the courts the power to create new and different fiduciary duties); id. app. B (listing the states and territories that have adopted the revisions). See generally Gerard C. Martin, Comment, Duties of Care Under the Revised Uniform Partnership Act, 65 U. CHI. L. REv. 1307 (1998) (providing an excellent analysis of the standard of care under RUPA).

${ }^{30}$ See UNIF. LTD. LIAB. CO. ACT $§ 103$ (1996) (following the RUPA approach to utilizing the statute in default of an agreement to the contrary, but arguably taking a more middle-of-the road approach by limiting the LLC. agreement's ability to unreasonably restrict access to information, eliminate the duty of loyalty, unreasonably reduce the duty of care, or eliminate the obligation of good faith and fair dealing); see

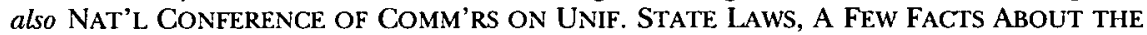
UNIFORM LIMITED LIABILITY COMPANY ACT, at http://www.nccusl.org/nccusl/uniform act_factsheets/uniformacts-fs-ullca.asp (last visited Feb. 23, 2004) (indicating that ULLCA has been adopted by Alabama, Hawaii, Illinois, Montana, South Carolina, South Dakota, U.S. Virgin Islands, Vermont, and West Virginia).

${ }^{31}$ See REVISED UNIF. P'SHIP ACT $\S 103$ (a) (establishing the authority of RUPA to govern absent a partnership agreement to the contrary); UNIF. LTD. LIAB. Co. ACT $\S 104$ (explaining that an operating agreement may modify or eliminate any rule except those matters specified in section 104(b) and providing in part that " $t \mathrm{t}] \mathrm{o}$ the extent not otherwise mentioned in subsection (b), every section of [the] Act is simply a default rule, regardless of whether the language of the section appears to be otherwise mandatory"); Hynes, supra note 29, at 34-35 (examining RUPA's efforts to enhance freedom of contract by "keep [ing] the list of mandatory duties as narrow as possible," but acknowledging the fact that RUPA does not give complete freedom to waive fiduciary duties).

${ }^{32}$ See, e.g., CAL. CORP. CODE $§ 17,005$ (West Supp. 2004) (providing that California's LLC statute governs relations among members " $[t]$ o the extent the articles of organization or operating agreement do not otherwise provide," but also placing some restrictions on the use of such private provisions); DEL. CODE ANN. tit. 6, § 18-305 
Delaware LLC statute stands out, however, for its lack of mandatory rules and its express policy to "give maximum effect to the principle of freedom of contract." ${ }^{33}$ Similarly, the ABA-drafted Prototype Limited Liability Company Act (PLLCA) contains statements regarding the duties of managers, but allows the operating agreement to eliminate, or at least limit, the personal liability of a member or manager for breaching fiduciary duties. ${ }^{34}$

The LLC legislation that has developed rests largely on a similar view that business participants should be free to strike their own business deals. This contractarian view of the business entity regards the firm as a "nexus of contracts." Under this approach, advocates for freedom from mandatory rules believe that business law should facilitate the private contracting of parties, with minimal judicial or statutory interference. ${ }^{36}$ Broad judicial rulings, particularly with regard to fiduciary duties, have been regarded with suspicion, especially by

(1999 \& Supp. 2002) (outlining members' and managers' rights to access LLC information but stating that the rights as provided may be restricted in the operating agreement); N.Y. LTD. LIAB. CO. LAW $\$ 402$ (McKinney 2004) (setting forth rules for voting rights to be applied "[e]xcept as provided in the operating agreement"); 15 PA. CoNS. STAT. ANN. $\$ 8942$ (West 1995 \& Supp. 2003) (establishing voting rules to be followed except as provided in the operating agreement); see also RIBSTEIN \& KEATINGE, supra note 7, apps. 5-1, 7-1 (containing chart summaries of state default allocation rules for profits, losses, and distributions, and waivers of fiduciary duties).

${ }^{33}$ DEL. CODE ANN. tit. 6, § 18-1101(b) (1999); see also \$ 18-108 (permitting an LLC to have the power to "indemnify and hold harmless any member or manager or other person from and against any and all claims and demands whatsoever"); Walker v. Res. Dev. Co., 791 A.2d 799, 813 (Del. Ch. 2000) (indicating that the basic approach of the Delaware LLC ACt is to confer broad discretion in drafting the LLC operating agreement and that, once members exercise this discretion, the specific terms of the agreement can then be enforced). A few other states have adopted similar "freedom of contract" language. See, e.g., GA. CODE ANN. § 14-11-1107(b) (2003); IDAHO CODE § 53668(1) (Michie 2000); N.M. STAT. ANN. § 53-19-65A (Michie 2001).

${ }^{34}$ See Prototype Ltd. Liab. Co. ACT $\$ \S 402,404$ (1993) (permitting the LLC agreement to eliminate or limit liability for breaches of fiduciary duties and allowing indemnification of members or managers).

${ }^{35}$ See Branson, supra note 26, at $395 \mathrm{n} .95$ (conceiving the firm as "nothing more than a 'nexus' or 'web' 'of contracts' among providers of capital, managers, lenders, labor, suppliers and consumers").

${ }^{36}$ See id. at 394 (stating that under the contractarian approach, "corporate law's only function should be to facilitate citizens' organization of their business affairs at the lowest possible cost"). But see Coffee, supra note 18, at 1619-20 (emphasizing the importance of the judicial role in monitoring and interpreting the corporate contract); see also Scott FitzGibbon, Fiduciary Relationships Are Not Contracts, 82 MARQ. L. REV. 303, 305 (1999) (asserting that fiduciary relationships "arise and function in ways alien to contractualist thought," particularly in that they "facilitate the doing of justice, ... promote virtue, and ... enhance freedom"). 
practitioners who have sought to limit their clients' liability through contractual arrangements. ${ }^{37}$

Conceptually, the "contractarian framework" sprang from the impact of economic theory upon business law. ${ }^{38}$ As explained by the English scholar Robert Goddard:

At a prescriptive, normative level, [the contractarian approach] provides a conceptual framework capable of resisting state intervention, and one in which the state's role is dual: first, to provide an appropriate mechanism for bargain enforcement; and, secondly, to provide a framework within which bargaining is made more efficient ....

In arguing for less government regulation, the contractarian scholars of the Chicago School of Economics have noted the importance of reducing transaction costs, emphasizing that the fiduciary paradigm for corporate governance interferes with the market for corporate control and impedes profit maximization. ${ }^{40}$ Under this view, if mandatory fiduciary duties are imposed, the parties will have an increased cost which will be passed on to consumers, resulting in an inefficient use of resources that will ultimately cause society to suffer. ${ }^{41}$

${ }^{37}$ See Donald J. Weidner, A Perspective to Reconsider Partnership Law, 16 FLA. ST. U. L. REV. 1, 38 (1988) (suggesting that reforms of the Uniform Partnership Act should focus on the duties of loyalty and care); Weidner, supra note 5 , at 462 (theorizing that RUPA $\S 21$ (b) was "motivated in part by a sense that vague, broad statements of a powerful duty of loyalty cause too much uncertainty"); see also Donald J. Weidner, RUPA and Fiduciary Duty: The Texture of Relationship, LAW \& CONTEMP. ProBS., Spring 1995, at 81, 86 (observing that RUPA offers "an attempt to add more determinacy to language that is often indeterminate"). But see Allan W. Vestal, Fundamental Error in the Revised Uniform Partnership Act of 1992, 73 B.U. L. REV. 523, 536-37 (1993) (arguing that RUPA is incapable of adapting to new and evolving situations, defeats participants' reasonable expectations, and sends the wrong societal message).

${ }^{38}$ See Stephen M. Bainbridge, Director Primacy: The Means and Ends of Corporate Governance, 97 Nw. U. L. REv. 547, 547-48 (2003) (remarking upon the increased role that economics has played in business law since Ronald $\mathrm{H}$. Coase's famous article, The Nature of the Firm, 4 ECONOMICA (N.S.) 386 (1937), and tracing contractarian theory back to that article); see also Robert Goddard, Enforcing the Hypothetical Bargain: Sections 459-461 of the Companies Act 1985, 20 COMPANY LAW. 66, 66-67 (1999) (discussing the remedy for unfairly prejudicial conduct under United Kingdom law and the theoretical framework of the contractarian view of the business entity).

${ }^{39}$ Goddard, supra note 38 , at 67-68.

40 See Thomas Lee Hazen, The Comporate Persona, Contract (and Market) Failure, and Moral Values, 69 N.C. L. REv. 273, 275-76 (1991) (discussing the attack by the Chicago School of Economics on the contract model of corporate governance).

${ }^{41}$ See Claire Moore Dickerson, Equilibrium Destabilized: Fiduciary Duties Under the Uniform Limited Liability Company Act, 25 STETSON L. REV. 417, 453-55 (1995) (explaining contractarian theory but criticizing its cost-sensitive approach to fiduciary duties). 
The contractarian model and its preoccupation with transaction costs, however, fail to consider the human relationships that develop in privately owned businesses. Indeed, the theoretical framework overlooks the vulnerability that has traditionally spurred the recognition of a fiduciary relationship, and distances itself from the actual and potential harm that minority-owners have historically experienced in the close corporation setting. ${ }^{42}$ The implicit value judgment underlying this contractarian view is that governmental policies based on interference and protectionism are inherently negative and should yield to the freedom of parties to contract on their own behalf. ${ }^{43}$

While some contractarians such as Professor Larry Ribstein are confident that market forces can control managerial misconduct, ${ }^{44}$ this reliance may well be misplaced in the context of the LLC since the private business entity lacks a ready market and is not required to present audited financial statements. ${ }^{45}$ Also, the assumption that fewer mandatory rules will result in decreased judicial intervention may not withstand the test of time. A recent study reported that the rate of lawsuits filed in connection with majority/minority disputes was significantly higher in Delaware, despite its enabling statute, than in the other states sampled. ${ }^{46}$ The rate of suits filed by Delaware

See generally O'NEAL \& THOMPSON, supra note 17 (providing an exhaustive treatise on the legal issues commonly encountered by the privately owned corporation).

${ }^{42}$ See Dickerson, supra note 41 , at $454-55$ (analyzing the contractarian view of relationships and concluding that this perspective "still neglects actual harm that can be suffered when fiduciary duties are not mandatory").

${ }^{43}$ See Daniel R. Fischel, The "Race to the Bottom" Revisited: Reflections on Recent Developments in Delaware's Corporation Law, 76 Nw. U. L. REV. 913, 944 (1982) (observing that corporate law has little role to play "[a]part from minimizing transaction costs and possibly facilitating the operation of market forces that discipline management").

${ }^{44}$ See Larry E. Ribstein, Bubble Laws, 40 Hous. L. REv. 77, 97 (2003) (suggesting that deregulation, rather than increased regulation, may be the answer to misconduct involving over-hyping, inadequate disclosure, or flimsy capital structures).

${ }^{45}$ See Christopher A. Riley, Contracting Out of Company Law: Section 459 of the Companies Act 1985 and the Role of the Courts, 55 MOD. L. REV. 782, 789 (1992) (arguing that shareholders of small companies are denied the protection that contractarians see in the market for corporate control because private companies are not traded).

${ }^{46}$ See Miller, supra note 12, at 394-95 (reporting the results of a survey of 770 practitioners and their experience working with LLCs in California, Delaware, New York, and Pennsylvania and observing that $50 \%$ of Delaware practitioners who had handled minority disputes said that a lawsuit had been filed, while only $21 \%, 9 \%$, and $25 \%$ indicated that suits had been instituted in California, New York, and Pennsylvania, respectively). See generally James R. Burkhard, LLC Member and Limited Partner Breach of Fiduciary Duty Claims: Direct or Derivative Actions?, 7 J. SMALl \& EMERGING BuS. L. 19, 45-51 (2003) (addressing LLC litigation and the question of whether a breach of fiduciary duty should be brought as a direct or derivative suit). 
practitioners who had handled majority/minority disputes was actually more than twice that of the other states considered. ${ }^{47}$ Vice Chancellor Jack B. Jacobs of the Delaware Court of Chancery recently described the remarkable volume of litigation spawned by alternative business entities in Delaware as problematic. ${ }^{48}$

Embedded within this inquiry lies a related question regarding the fairness of the contractarian vision in representing the needs of the business community at large. Depending on the extent to which it fails to consider the interests of the less sophisticated and less financially privileged small entrepreneurs who may not be well represented by legal counsel, the contractarian model may be positioning certain LLC members at an initial disadvantage that is impossible to surmount. $^{49}$

Ultimately, the wisdom of the contractarian vision of corporate law, and its influence on business culture, may well be questioned in the wake of the Enron debacle and subsequent accounting scandals. ${ }^{50}$

${ }^{47}$ Miller, supra note 12 , at $394-95$.

48 Jacobs, supra note 12, at 1044-45.

49 See Barbara Ann Banoff, Company Governance Under Florida's Limited Liability Com pany Act, 30 FLA. ST. U. L. REV. 53, 79-80 (2002) (observing that the unsophisticated LLC owner (the "do-it-yourselfer") may be unpleasantly surprised by the lack of a default buyout rule in the revised Florida LLC statute); see also COMM. ON CORPORATE LAWS, ABA SECTION OF BUS. LAW, MANAGING CLOSELY HELD CORPORATIONS: A LEGAL GUIDEBOOK (2003), reprinted in 58 BUS. LAW. 1073, 1077-1126 (2003) (providing some direction and guidance to nonlawyers by offering "a concise, practical overview of important legal principles governing directors, officers and shareholders of closely held corporations").

${ }^{50}$ For background on the Enron collapse, see Kurt Eichenwald \& Diana B. Henriques, Enron Buffed Image to a Shine Even as It Rotted from Within, N.Y. TIMES, Feb. 10, 2002, at 1 (detailing the company's use of alternative entities to hide debt); Wendy Zellner, The Fall of Enron, BUS. WK, Dec. 17, 2001, at 30 (indicating that Enron had about $\$ 20$ billion of undisclosed off-balance-sheet partnership debt for which it was liable). There is much debate over the appropriate regulatory response to the Enron collapse. See, e.g., Faith Stevelman Kahn, Bombing Markets, Subverting the Rule of Law: Enron, Financial Fraud, and September 11, 2001, 76 TUL. L. REV. 1579, 1615 (2002) (arguing for a more activist approach to corporate regulation despite the prevailing sentiment among academics and practitioners that regulatory minimalism promotes profitability and economic efficiency); David Millon, Why is Corporate Management Obsessed with Quarterly Earnings and What Should Be Done About It?, 70 GEO. WASH. L. REV. 890, 913 (2002) (discussing the need to remove the legal structures that fuel management's drive to meet analysts' expectations); Robert B. Thompson, Corporate Governance After Enron, 40 HOUS. L. REV. 99, 107-11 (2003) (questioning why the states did not do more in response to the severity of the governance problems exposed after Enron and observing that state corporate statutes provide only minimal control over corporate power by subjecting directors to judicially imposed fiduciary duties while leaving the markets to regulate everything else). But see Ribstein, supra note 44, at 89 (criticizing the Sarbanes-Oxley Act as "regulat[ion] in a panic" that "ignored potential market 
In conceptualizing the relationship among owners of the private business, the contractarian approach shifts the focus from a broad-based fiduciary-oriented regime to one that narrowly identifies the participant's contractual obligations. This perspective places primary emphasis upon one's freedom to pursue one's self-interest, rather than upon one's duties and obligations with respect to others and to the business enterprise itself. As Allan W. Vestal observes:

Historically, the core of the "fiduciary's duty is an attitude, not a rule" for partnerships, as well as for close corporations. It is detrimental to substitute rules that invite evasion, for social principles that foster broad compliance. Abandonment of fiduciary principles may be efficient for some participants, but it is not beneficial to society.

Recent accounting scandals serve as a warning against business cultures that place insufficient limits upon conflicts of interest and self-interested conduct and that fail to adequately emphasize the importance of one's responsibilities to others.

\section{Diverse LLC STATUTORY TREATMENT OF FIDUCIARY DUTIES}

The LLC presents an interesting challenge to existing theories of corporate governance because of its hybrid nature. Based partially on both the partnership and corporation models, the LLC is an alternative business entity that does not always fit into existing legal paradigms. Will partnership and/or corporate precedents for the standard of conduct and duty of loyalty apply? $?^{52}$ Should contractual obligations of good faith be used to resolve an LLC member dispute rather than fiduciary duties? $?^{53}$ What theories should apply if there is

solutions to corporate fraud"); Larry E. Ribstein, Market vs. Regulatory Responses to Corporate Fraud: A Critique of the Sarbanes-Oxley Act of 2002, 28 J. CORP. L. 1, 61 (2002) (suggesting that " $[\mathrm{m}]$ arkets are capable of responding more quickly and precisely than regulation to corporate fraud").

${ }^{51}$ Vestal, supra note 37, at 539-40 (quoting Chiles v. Robertson, 767 P.2d 903, 912 (Or. Ct. App. 1989)).

${ }^{52}$ See Sandra K. Miller, What Standards of Conduct Should Apply to Members and Managers of Limited Liability Companies?, 68 ST. JOHN's L. REV. 21 (1994) (comparing partnership, corporate, and agency standards of conduct as possible precedents for LLC standards of conduct); see generally Sandra K. Miller, What Buy-out Rights, Fiduciary Duties, and Dissolution Remedies Should Apply in the Case of the Minority Owner of a Limited Liability Company?, 38 HARV. J. ON LEGIS. 413 (2001) (discussing the need to provide corporate buyout rights to minority LLC members).

${ }^{53}$ See Jacobs, supra note 12, at 1044 (arguing that courts have to develop an entirely new predicate layer of analysis that requires the court to decide which set of 
no written operating agreement? Should heightened fiduciary duties apply in a case involving a majority owner of a small private LLC and a minority participant?

The answers to these questions are not obvious. As it stands, the results in any particular dispute depend, in part, upon the diverse body of enabling legislation, the LLC operating agreement, and the particular court's fiduciary duty jurisprudence. It has not been clear to what extent a given dispute should be settled with reference to contract law or to fiduciary principles, and if fiduciary principles apply, whether the reference should be made to partnership or corporate principles.

Under the common law, fiduciary duties are imposed upon parties who are entrusted with special degrees of responsibility and trust. ${ }^{54}$ In the trustee/beneficiary context, the trustee owes fiduciary duties to the beneficiary. ${ }^{55}$ In partnership law, partners owe fiduciary duties to both the partnership and the other partners, and in the corporate realm, directors owe fiduciary duties to the shareholders. ${ }^{56}$

In both partnership and corporate law, fiduciary duties generally include both a duty of care and a duty of loyalty. ${ }^{57}$ The duty of care is generally regarded as the duty to be attentive and informed before making a decision that affects the corporation. ${ }^{58}$ The duty of loyalty

principles-“fiduciary law, contract law, or a combination of both"-apply in a particular case).

${ }_{54}^{5}$ See Tamar Frankel, Fiduciary Law, 71 CAL. L. Rev. 795, 800 (1983) (noting that in the fiduciary relation, one party, the entrustor, is dependent upon the other party, the fiduciary).

${ }^{55}$ See $i d$. at 801 (describing how a fiduciary may "enter into a fiduciary relation without regard to his own needs").

${ }^{56}$ See Victor Brudney, Contract and Fiduciary Duty in Corporate Law, 38 B.C. L. REv. $595,624-25$ (1997) (indicating that in the case of trusts, principal and agent relationships, and corporate management, the fiduciary must act for the beneficiary's exclusive benefit, and that in the case of partnership or corporate controllers, the fiduciary must act for the beneficiary's shared benefit in proportions designated ex ante).

${ }^{57}$ See 1 PRINCIPLES OF CORPORATE GOVERNANCE: ANALYSIS AND RECOMMENDATIONS 137 (1994) (indicating that the legal obligations of directors and officers have been traditionally divided into the categories of duty of care and duty of loyalty); see also BISHOP \& KLEINBERGER, supra note 7, II 10.01[1][a]-[b] (providing an overview of fiduciary duties in the LLC and discussing the components of duty of care and duty of loyalty); RIBSTEIN \& KEATINGE, supra note 7, $\$ \$ 9.10-11$ (comparing the duties of LLC managers with the corporate and partnership duty of care and duty of loyalty); $c f$. Paul M. Altman et al., Contractually Defining Duties of General Partners in Delaware Limited Partnerships, 19 A.B.A. SEC. Bus. L. Newsl. COMM. ON PARTNERSHIPS \& UNinCorPORATED BUS. ORGS. 8, 8 (2002) (offering an overview of general partners' fiduciary duties).

58 1 PRINCIPLES OF CORPORATE GOVERNANCE, supra note 57, at 137. 
imposes a duty to conduct oneself in a manner that furthers the best interests of the partnership or the corporation. ${ }^{59}$

With regard to the standard of care, PLLCA provides that a member or manager of the LLC will not be liable or accountable for damages or otherwise unless the act or omission constitutes gross negligence or willful misconduct. ${ }^{60}$ ULLCA similarly employs a gross negligence standard. ${ }^{61}$ Comments contained in PLLCA observe that the gross negligence standard of care is analogous to the standard commonly applied to corporate directors, managing partners, or general partners of limited partnerships. ${ }^{62}$ State LLC statutes vary with respect to the standard of care articulated. Some states, including Delaware, fail to adopt any express standard of care, ${ }^{63}$ others utilize the gross negligence or willful misconduct language ${ }^{64}$ while still others employ language similar to that applied to directors under the Model Business Corporation Act (MBCA) ${ }^{65}$ Among the latter group, some establish standards of conduct for managers but not for members. ${ }^{66}$

${ }^{59} I d$. (noting that the duty of loyalty entails the commitment of allegiance to the enterprise such that the best interests of the corporation and shareholders must prevail over individual interests).

${ }^{60}$ Prototype LTD. LIAB. Co. ACT $\$ 402$ (A) (1993). The Business Law Section of the American Bar Association is currently working on a revision of PLLCA. Also, the National Conference of Commissioners on Uniform State Laws is in the process of revising ULLCA.

See UNIF. LTD. LiAB. Co. ACT $\$ 409$ (c) (1996) (stating that a partner's duty of care is to refrain from engaging in grossly negligent or reckless conduct, intentional misconduct, or a knowing violation of law).

${ }^{62}$ In particular, PLLCA provides the following commentary to section 402(A):

Subsection (A) sets forth the gross negligence standard of care for those participating in management. This is similar to the standard commonly applied to corporate directors, managing partners, or general partners of limited partnerships. In general, as long as managers avoid self-interested and grossly negligent conduct, their actions are protected by the business judgment rule.

Prototype LtD. LiAB. Co. ACT § 402(A); see also RiBSTEIN \& KEATINGE, supra note 7, app. 9-1 (summarizing the various standards of care by state).

${ }^{63}$ See DEL. CoDE ANN. tit. 6, § 18-1101 (1999) (providing no express standards of conduct for members and managers but indicating that an operating agreement may expand or restrict any duties at law or equity); TEX. BUS. CORP. ACT ANN. arts. 2.12-.20 (1999) (containing rules pertaining to managers but failing to specify a standard of care). Other states that fail to provide a statutory duty of care include Arizona, Kansas, Nebraska, Nevada, South Dakota, Utah and Wyoming. THOMAS A. HuMPHREYS, LiMITED LIABILITY COMPANIES $\$ 4.02(3)$ n.55 (1998).

${ }^{64}$ For a list of statutes taking this approach, see infra Appendix B tbl.2.

${ }^{65}$ See MOD. BuS. CORP. ACT $\$ 8.30$ (rev. 2002) (mandating that directors act "(1) in good faith, and (2) in a manner the director reasonably believes to be in the best interests of the corporation"). For a list of statutes adopting this type of language, see infra Appendix B tbl.l. See also BISHOP \& KLEINBERGER, supra note 7, I 10-16 (sorting 
The statutory treatment of the duty of loyalty applicable to LLC members and managers is also quite diverse. Although some LLC statutes are silent as to fiduciary duties, ${ }^{67}$ others contain express statements that the fiduciary duties of members and/or managers are limited to those specifically designated in the statute-for example, duties to account for certain benefits, to refrain from dealing with the LLC on behalf of an adverse party, or to refrain from competing with the LLC. ${ }^{68}$ ULLCA has taken the latter approach. ${ }^{69}$

ULLCA's duty-to-account language has roots in the Uniform Partnership Act (UPA) ${ }^{70}$ and is included in RUPA, in addition to specific statements regarding dealing in interests that are adverse to that of the partnership and competing directly with the partnership business. ${ }^{71}$ Some statutes have likewise included a requirement to account

the duty of care provisions into five categories); RIBSTEIN \& KEATINGE, supra note 7 , app. 9-1 (containing a chart categorizing the standards of care in different states).

${ }^{60}$ See, e.g., COLO. REV. STAT. $\$ 7-80-406$ (1999) (identifying the duties and standards for managers but not specifying explicit standards for members).

${ }^{67}$ See, e.g., Al.ASKA STAT. $\$ 10.50 .130$ (Michie 2002) (providing that unless otherwise provided in the operating agreement, the member does not have the fiduciary duty of a manager); ARK. CODE ANN. \$ 4-32-402 (Michie 1997) (containing no statements about the duty of good faith or loyalty); DEL. CODE ANN. tit. 6, § 18-1101 (1999 \& Supp. 2002) (avoiding any statement on fiduciary duties by indicating that, "to the extent that, at law or in equity, a member or manager or other person has duties (including fiduciary duties) and liabilities," any such person shall not be liable for the good faith reliance on the provisions of the LLC agreement, and the duties and liabilities may be expanded or restricted by the agreement); D.C. CODE ANN. $\$ 29-1021$ (2001) (containing no restrictions on transactions between members or managers and the LLC).

${ }^{68}$ See ALA. CODE $§ 10-12-21$ (f) (1999) (indicating that a member's duty of loyalty in a member-managed LLC is limited to (1) accounting and holding as trustee any of the LLC's property, profit, or benefit including the appropriation of the LLC's opportunity, (2) refraining from dealing with the LLC as or on behalf of a party having an adverse interest, and (3) refraining from competing with the LLC); CAL. CORP. CODE $\$ 17,154$ (West Supp. 2004) (providing that the fiduciary duties that a manager owes to the LLC and its members are those of a partner to a partnership); HAW. REV. STAT. $\$$ 428-409 (Supp. 2001) (indicating that the duty of loyalty is limited to accounting for property, profits, or benefits; refraining from dealing with the LLC as an adverse party; and refraining from competing with the LLC); 805 ILL. COMP. STAT. 180/15-3 (West Supp. 2003) (declaring that the fiduciary duties include the duty to account for certain benefits, to act fairly when acting on behalf of a party with an adverse interest to the company, and to refrain from competing with the company); see also BISHOP \& KLEINBERGER, supra note 7, I 10-16 (classifying the duty of loyalty provisions into four categories).

${ }^{69}$ UNIF. LTD. LiAB. Co. ACT $§ 409$ (1996).

${ }^{70}$ UNIF. P'SHIP ACT (amended 1997), 6 U.L.A. 143 (pt. I) (2001).

${ }^{71}$ Section 404(b) of UPA, provides in part:

A partner's duty of loyalty to the partnership and the other partners is limited to the following: 
to other members for profits made from LLC transactions as a specific element of the duty of loyalty. ${ }^{72}$

The statutes also vary in the extent to which they permit contractual modifications to the statutory standards for fiduciary duties. Many LLC statutes even contain express restrictions on the right to contractually modify the member's or manager's standards of conduct in the articles of organization or operating agreement. ${ }^{73}$

In spite of the broad similarities between partnership and corporate fiduciary duties, some commentators have observed that judicial oversight of fiduciary duties has been more exacting with regard to

(1) to account to the partnership and hold as trustee for it any property, profit, or benefit derived by the partner in the conduct and winding up of the partnership business or derived from a use by the partner of partnership property, including the appropriation of a partnership opportunity;

(2) to refrain from dealing with the partnership in the conduct or winding up of the partnership business as or on behalf of a party having an interest adverse to the partnership; and

(3) to refrain from competing with the partnership in the conduct of the partnership business before the dissolution of the partnership.

Section 409 of ULLCA contains substantially similar language. UNIF. LTD. LIAB. Co. ACT $\$ 409$.

72 See HUMPHREYS, supra note $63, \S 4.02(3)$ (b) (indicating that one group of LLC statutes tracks section 21 of UPA and requires accounting to other LLC members). Section 21 of UPA provides that:

Every partner must account to the partnership for any benefit, and hold as trustee for it any profits derived by him without the consent of the other partners from any transaction connected with the formation, conduct, or liquidation of the partnership or from any use by him of its property.

UNIF. P'SHIP ACT $\$ 21$ (1) (amended 1997), 6 U.L.A. 194 (pt. II) (2001). A number of LLC statutes adopt similar language pertaining to the duty to account to other members for profits.

${ }^{73}$ See, e.g., ALA. CODE $\$ 10-12-21$ (1) (1999) (noting that an operating agreement may modify a member's or manager's duties but may not unreasonably restrict rights to information or records or eliminate the duty of loyalty); COLO. REv. STAT. ANN. $\$ 7$ 80-108 (2003) (providing that an operating agreement may not unreasonably restrict access to books and records, unreasonably reduce the duty of care, or eliminate good faith requirements); DEL. CODE ANN. tit. 6, \$18-1101 (c) (Supp. 2002) (providing that, to the extent a member or manager has duties at law or in equity, including fiduciary duties and liabilities relating to the LLC or to another member or manager, the member or manager shall not be liable for good faith reliance on the operating agreement and the operating agreement may expand or restrict the person's duties and liabilities); D.C. CODE ANN. $§ 29-1020$ (a) (2001) (indicating that liability may be limited or eliminated in the articles of organization except if the manager or member engaged in willful misconduct); FLA. STAT. ANN. § 608.423(2)(a)-(c) (West 2001 \& Supp. 2004) (providing that the agreement may not unreasonably restrict the right to information or records, eliminate the duty of loyalty, or unreasonably reduce the duty of care); see also RIBSTEIN \& KEATINGE, supra note 7, app. 9-1 at 11 (summarizing the state provisions dealing with waivers of fiduciary duties in LLCs). 
partnerships than with regard to public corporations. ${ }^{74}$ While a corporate director must swear allegiance to the enterprise, place the best interests of the corporation and the shareholders before her own, and not exploit her position for personal profits, she is nevertheless permitted to engage in a self-dealing transaction or outside activity if it is "fair" to the corporation. ${ }^{75}$ In contrast, the partnership rule is arguably more demanding insofar as a partner may not receive an individual profit without the consent of the other partners. ${ }^{76}$

A stricter interpretation of the duty of loyalty and increased judicial oversight have traditionally been observed in partnerships, where, as Chief Judge Benjamin Cardozo eloquently stated in the famous case Meinhard v. Salmon, ${ }^{77}$ copartners "owe to one another ... the duty of finest loyalty .... Not honesty alone, but the punctilio of an honor the most sensitive ...."78 Although, in general, one corporate shareholder does not owe a fiduciary duty to another corporate shareholder, it may be argued that shareholders of a private corporation should owe a fiduciary duty to fellow shareholders insofar as the private corporation functions like an incorporated partnership. Thus, a heightened duty of loyalty has been extended to close corporations in some jurisdictions. $^{79}$

This movement to extend heightened fiduciary duties to the close corporation setting has met strong resistance, with critics cynically

${ }^{74}$ See John C. Coffee, Jr., No Exit?: Opting Out, the Contractual Theory of the Corporation, and the Special Case of Remedies, 53 BROOK. L. REV. 919, 940 (1988) (positing that, "in the case of the partnerships and close corporations, courts seem to have been stricter in the enforcement of fiduciary duties than in the case of publicly held corporations").

${ }^{75}$ As the MBCA suggests:

A director's conflicting interest transaction may not be enjoined, set aside, or give rise to an award of damages or other sanctions, in a proceeding by a shareholder or by or in the right of the corporation, because the director, or any person with whom or which he has a personal, economic, or other association, has an interest in the transaction, if ... the transaction, judged according to the circumstances at the time of commitment, is established to have been fair to the corporation.

MOD. BUS. CORP. ACT $\$ 8.61$ (b) (rev. 2002).

${ }^{76}$ See RIBSTEIN \& KEATINGE, supra note 7, \$ 9.10, at 35-36 (claiming that corporate managers are subject to a lesser standard than general partners based on the "fairness" exception in the corporate context).

7164 N.E. 545 (N.Y. 1928).

${ }^{78} I d$. at 546.

${ }^{79}$ See, e.g., Donahue v. Rodd Electrotype Co. of New Eng., 328 N.E.2d 505, 515-17 (Mass. 1975) (applying the more exacting duties of a partnership to a close corporation based on the similar levels of trust and confidence that govern both kinds of business relationships). 
referring to it as "galloping Meinhardism." Contractarians argue that "[f]iduciary duties are standard form terms that are not appropriate for many firms" and that "the parties might reasonably decide that standard form duties are prohibitively costly." Thus, while traditionalists largely view fiduciary duties as moral mandates, ${ }^{82}$ contractarians perceive them as economic choices. Left with this basic conflict in ideology, Delaware has attempted to steer its way toward a reasoned solution. At least with respect to the argument for heightened fiduciary duties in the close corporation context, Delaware has followed the contractarian view by refusing to recognize any alteration in the majority's fiduciary duties simply because the company is a close corporation.

The debate surrounding the mandatory imposition of heightened fiduciary duties in the context of private business entities, and in the LLC particularly, pits the interest in freedom of contract against the need to both curtail abusive conduct and foster accountability. This clash of principles initially unfolded in the partnership context in contentious discussions surrounding the enactment of RUPA. ${ }^{84}$ RUPA places limits on waivers of fiduciary duties but ultimately attempts to halt "galloping Meinhardism" by stating that there are only two

${ }^{80}$ Banoff, supra note 49 , at 59.

${ }^{81}$ RIBSTEIN \& KEATINGE, supra note 7, § 9.04, at 12.

${ }^{82}$ See Banoff, supra note 49 , at 59 (describing the traditionalists' view of fiduciary duties in the ongoing debate with contractarians); see also Lawrence E. Mitchell, The Death of Fiduciary Duty in Close Corporations, 138 U. PA. L. REv. 1675, 1677-82 (1990) (arguing that courts have implicitly rejected the assumptions on which fiduciary duties are based and now seem content to rely on "the morals of the marketplace" rather than some more abstract, higher standard).

${ }^{83}$ See Riblet Products Corp. v. Nagy, 683 A.2d 37, 39 n.2 (Del. 1996) (noting that, in a lawsuit for breach of fiduciary duty brought by a minority shareholder/employee, the business's status as a closely held company did not alter the duties of the majority or minority shareholders); Nixon v. Blackwell, 626 A.2d 1366, 1379-81 (Del. 1993) (refusing to develop any judicially created rules to protect minority investors of closely held, but not statutory close corporations); Olsen v. Seifert, No. 97-6456, 1998 Mass. Super. LEXIS 592 (Mass. Super. Ct. Aug. 28, 1998) (indicating that Delaware would review a particular transaction for overall fairness where it is alleged that a controlling shareholder has benefited excessively, but will not impose broad fiduciary duties on close corporations); see also Theresa L. Kelly, Recent Development, Nixon v. Blackwell: Faimess but Not Equality for Minority Shareholders, 19 DEL. J. CORP. L. 533, 533 (1994) (“[T] he court made it clear that minority shareholders in closely-held corporations are not entitled to special judicially-created protections.").

${ }_{84}$ Compare Hynes, supra note 29, at 31 (arguing that RUPA endorses too great an invasion into the freedom of contract), with Vestal, supra note 37, at 524-25 (arguing that the contractarian error in RUPA is so basic and the effects are so profound that the National Conference of Commissioners on Uniform State Laws should withdraw the act). 
overarching fiduciary duties: the duty of care and the duty of loyalty, the latter being divided further into the duty to account, the duty not to deal with the partnership as an adversary, and the duty not to compete. ${ }^{85}$

The legal community has eagerly awaited case law to establish the parameters of these LLC member and manager fiduciary duties. In this regard, a variety of questions have been raised. For instance, will courts apply corporate fiduciary duties to LLCs that resemble small partnerships or close corporations in which the LLC owner may have an illiquid investment or will they instead employ heightened partnership-style fiduciary duties? Will increased judicial scrutiny apply to an LLC that resembles a limited partnership because of the special level of trust that nonmanaging LLC members may place in the LLC manager? To what extent will courts intervene to impose mandatory standards to curb abusive conduct, notwithstanding the fact that the LLC is designed to be a creature of private contracting? And finally, to what extent will courts respect contractual limitations on fiduciary duties?

Cases involving allegations of breach of fiduciary duties are beginning to emerge, and the discussion below separately analyzes selected cases both outside and inside Delaware. Clearly, the cases do not fully answer the many questions that LLCs raise. Nevertheless, some guidance is provided. Outside of Delaware, courts are assuming control over abusive conduct through the application of partnershipand corporate-style fiduciary duties. Within Delaware, courts have consistently refused to impute heightened fiduciary duties to LLCs because of the closely held nature of the LLC. At the same time, however, Delaware courts are exercising some control over abusive conduct, primarily by requiring the defendant to meet the entire fairness standard in conflict-of-interest transactions. This rigorous use of entire fairness may indeed become the source of considerable protection for minority LLC owners in cases that involve self-dealing in overt squeeze-outs, notwithstanding Delaware's commitment to private ordering and refusal to assign heightened fiduciary duties to closely held business enterprises. ${ }^{86}$

${ }^{85}$ REVISED UNIF. P'SHIP ACT $\S 404(\mathrm{a})-(\mathrm{b})$ (1997); see also UNIF. LTD. LIAB. Co. ACT $\$ 409(a)-(b)$ (1996) (enumerating the requirements imposed by the duty of loyalty).

${ }^{86}$ See Robert A. Ragazzo, Toward a Delaware Common Law of Closely Held Corporations, 77 WASH. U. L.Q. 1099, 1142-44 (1999) (maintaining that Delaware's entire fairness test may provide substantial protection against overt squeeze-outs but may not be as 


\section{JUDICIAL MONITORING OF FIDUCIARY DUTIES OUTSIDE DELAWARE}

Long-awaited judicial interpretations of fiduciary duties are also developing outside Delaware. Several of these cases involve typical patterns of abusive conduct that are commonly seen in a close corporation such as the theft of LLC property, ${ }^{87}$ the improper transfer of LLC assets to other entities, ${ }^{88}$ the usurpation of LLC clients, ${ }^{89}$ and the squeeze-out of minority members. ${ }^{90}$

The judiciary appears, in at least one decision, to use partnership and corporate formulations of fiduciary duties somewhat interchangeably to combat such abusive conduct. In Fine $v$. Bork, ${ }^{91}$ a Connecticut case involving the theft of LLC real property, the court referred to both partnership and corporate formulations of fiduciary duties to condemn the defendants' conduct. ${ }^{92}$ This type of dual referencing is supported in the Connecticut LLC statute itself, which contains partnership language (e.g., the duty-to-account), as well as corporate-style formulations (e.g., the duty to discharge duties in good faith with the care of an ordinarily prudent person in like position).$^{93}$

As indicated previously, some statutes apply a corporate standard of care to LLC managers, and consequently, one would expect case law to apply corporate precedents. Not surprisingly, in Flippo v. CSC Associates III, ${ }^{94}$ where the Virginia LLC statute holds an LLC manager

effective in combating more subtle types of abuse such as the failure to pay dividends and the attempt to purchase shares at a bargain price).

${ }^{87}$ See Fine v. Bork, No. 010808586, 2002 Conn. Super. LEXIS 181, at *1 (Conn. Super. Ct. Jan. 15, 2002) (concerning the unlawful appropriation of LLC real estate property by the majority owner).

${ }_{88}$ See Flippo v. CSC Assocs. III, 547 S.E.2d 216, 220 (Va. 2001) (recounting the unilateral transfer of an LLC's assets to a new entity in order to achieve personal estate planning goals).

${ }^{89}$ See Credentials Plus, L.L.C. v. Calderone, 230 F. Supp. 2d 890, 896-900 (N.D. Ind. 2002) (holding that a former LLC manager's solicitation of LLC clients for her new venture constituted an improper seizure of LLC business opportunities).

${ }^{90}$ See Anest v. Audino, 773 N.E.2d 202, 205-08 (Ill. App. Ct. 2002) (presenting a claim brought by an LLC member that was excluded from participation in an exclusive distributorship), appeal denied, 787 N.E.2d 154 (Ill. 2002).

${ }^{91} 2002$ Conn. Super. LEXIS 181.

${ }^{92}$ Id , at $* 5-6$.

${ }^{93}$ CONN. Gen. STAT. ANN. \$ 34-141(a), (e) (West 1997 \& Supp. 2003).

${ }^{94} 547$ S.E.2d 216. 
to the standard applicable to corporate directors, ${ }^{95}$ the court embraced a corporate formulation of fiduciary duties. ${ }^{96}$

In contrast, in Credentials Plus, $L L C v$. Calderone, ${ }^{97}$ an Indiana decision involving the usurpation of business opportunities, the court applied partnership standards of fiduciary duty to the LLC. ${ }^{98}$ According to the court, Indiana law provides that shareholders of close corporations owe partnership-like fiduciary duties to fellow shareholders. ${ }^{99}$ The gravitation toward partnership fiduciary duties was also supported by the partnership-like duty-to-account language found in Indiana's LLC statute. ${ }^{100}$

Even absent statutory language imposing expressly stated fiduciary duties on members, it is nevertheless possible for courts to impose such duties based on corporation, close corporation, or partnership case law in the jurisdiction. For example, in Anest $v$. Audino, ${ }^{101}$ an Illinois case involving a squeeze-out from the opportunity to participate in an exclusive distributorship, the statute did not specifically establish a standard of care during the time period in question. Relying on corporate law principles, however, the court held that LLC members and managers had obligations similar to corporate directors. ${ }^{102}$ The court then concluded that the defendant had breached his fiduciary duties to the plaintiff by failing to properly disclose and tender the opportunity to the LLC, basing its decision on the corporate opportunity doctrine and close corporation precedents that imposed partnership-like fiduciary duties upon shareholders of close corporations. ${ }^{103}$

95 See VA. CODE ANN. $§ 13.1-1024.1$ (A) (Michie 1999) (requiring LLC managers to discharge their duties in accordance with their "good faith business judgment of the best interests of the limited liability company").

${ }_{96}$ Flippo, 547 S.E.2d at 221.

${ }^{97} 230$ F. Supp. 2d 890 (N.D. Ind. 2002).

${ }^{98}$ Id. at 898-99.

${ }^{99}$ Id.

${ }^{100}$ See IND. CODE ANN. $\$ 23-18-4-2$ (West 1994) (containing relevant material in $\S 2$ (a) limiting liability unless the conduct was willful or reckless, $\$ 2$ (b) forcing each member and manager to account for certain benefits and profits unless otherwise provided in the operating agreement, and $\$ 2$ (c) indicating that a member who is not a manager does not have duties to the LLC or other members solely by acting as a member).

${ }^{101} 773$ N.E.2d 202 (Ill. App. Ct. 2002), appeal denied, 787 N.E.2d 154 (Ill. 2002).

${ }^{102}$ Id. at 210.

${ }^{103}$ See id. at 209-11; see also 805 ILL. COMP. STAT. 180/15-3 (West Supp. 2003) (stating that members in a member-managed LLC owe to each other fiduciary duties of loyalty and care); 805 ILL. COMP. STAT. 180/55-15 (West Supp. 2003) (applying the 
While these cases contain different mixes of partnership- and/or corporate-style statements of fiduciary duties, a common theme emerges. Whether under the guise of partnership or corporate formulations of fiduciary duty, the courts appear willing to police the more obvious patterns of opportunistic conduct ranging from theft of property to usurpation of opportunities.

\section{A. Unilateral Dissolutions Designed to Seize or Control LLC Assets or Business Affairs}

As indicated above, Fine v. Bork, the Connecticut LLC case involving the usurpation of real property, was decided against the backdrop of the Connecticut LLC statute, which integrates both traditional partnership and long-standing corporate notions of fiduciary duty. ${ }^{104}$ The plaintiff and the defendant owned a parcel of commercial real estate indirectly through two LLCs, Tower Business Associates (Associates) and Tower Business Center (Center), with the real estate owned by Center. ${ }^{105}$ When the relationship between the plaintiff and the defendant broke down, the defendant unilaterally and without the plaintiff's prior consent amended Center's operating agreement to allow it to exist with one member. The defendant then dissolved Associates, making himself the sole member of Center and the sole owner of the commercial real estate. ${ }^{106}$

The plaintiff filed a notice of lis pendens against the property of Center, and the court denied the defendant's motion to dissolve the notice against the property. ${ }^{107}$ The court concluded that the defendant had violated the classic corporate-style standard of care contained in Connecticut's statute that requires members or managers to discharge their duties both in good faith, "with the care an ordinary prudent person in a like position would exercise under similar circumstances," and in the best interests of the LLC. ${ }^{108}$ The court also rested its decision on the statutory "duty-to-account" language requiring every member and manager to account to the LLC and hold as trustee for it any benefit derived by that person without the consent of

fiduciary duties of section $180 / 15-3$ to existing LLCs only on their election prior to January 1, 2000).

${ }^{104}$ Supra notes $91-93$ and accompanying text.

${ }^{105}$ No. 010808586, 2002 Conn. Super. LEXIS 181, at *2-3 (Conn. Super. Ct. Jan. $15,2002)$.
${ }^{106} I d$. at $* 3-4$.
107 Id. at $* 7$.
${ }^{108} I d$. at $* 5$. 
the majority of the disinterested managers or the majority in interest of the disinterested members. ${ }^{109}$ This latter provision is very similar to the "duty-to-account" language in the Uniform Partnership Act and the Revised Uniform Partnership Act. ${ }^{110}$

In Flippo v. CSC Associates III, ${ }^{111}$ the Supreme Court of Virginia also used a traditional corporate-style formulation of the standard of care and the business judgment rule to award compensatory and punitive damages against the manager of an LLC who, in order to achieve his own estate planning goals, transferred the LLC assets to another entity without the prior knowledge or consent of the other members. ${ }^{12}$

Flippo Land \& Timber Co., L.L.C. (FLTC) was created to hold the assets which consisted of family-owned timberlands. ${ }^{113}$ Three members of the family had created their own LLC, CSC Associates III, which in turn owned their part interests in FLTC. ${ }^{114}$ In turn, those three family members-through CSC Associates III-refused to permit the other members of FTLC to create separate LLCs to hold their own interests in FLTC. ${ }^{115}$ Thereafter, the defendant, Carter Flippo, dissolved FLTC, transferred its non-cash assets to a new venture, and offered CSC the option of joining the new venture if the members agreed to the terms of its operating agreement. ${ }^{116}$

The court upheld the imposition of compensatory and punitive damages against the defendant, relying on an LLC statute that embraced a corporate-style formulation of the business judgment rule. ${ }^{17}$ The Virginia statute states that an LLC manager must discharge her duties in accordance with a good faith business judgment of the best interests of the LLC. ${ }^{118}$ In upholding the lower court's finding that

${ }^{109}$ Id. at $* 6$ (citing CONN. GEN. STAT. ANN. $\S 34-141$ (e) (West 1997 \& Supp. 2003)).

${ }^{110}$ See UNIF. P'SHIP ACT $\$ 21$ (1) (amended 1997), 6 U.L.A. 194 (pt. II) (2001) ("Every partner must account to the partnership for any benefit, and hold as trustee for it any profits derived by him without the consent of the other partners ...."); REVISED UNIF. P'SHIP ACT $\$ 404$ (b) (1), 6 U.L.A. 143 (pt. I) (2001) (requiring a partner "to account to the partnership and hold as trustee for it any property, profit, or benefit derived by the partner in the conduct and winding up of the partnership business or derived from a use ... of partnership property").

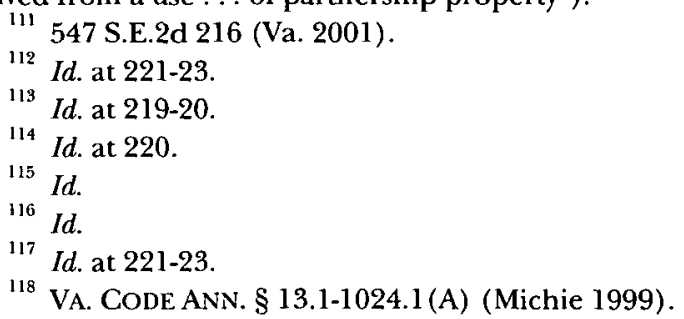


Carter Flippo was liable for a breach of fiduciary duty, the Supreme Court of Virginia emphasized that Flippo had transferred the LLC's assets not to further the business interests of the LLC, but rather to achieve his personal estate planning goals. ${ }^{119}$

\section{B. Traditional Judicial Monitoring to Police Diversion of LLC Business Opportunities}

As many expected, some courts are using traditional partnershipstyle fiduciary duties to combat unfair appropriations of LLC opportunities. Chief Judge Cardozo's admonishment that partners owe each other "the duty of the finest loyalty" ${ }^{20}$ first permeated partnership law, then close corporation law. It is now beginning to color the development of LLC law as courts seek to establish a fiduciary core that is applicable to LLC participants.

In Credentials Plus, L.L.C. v. Calderone, ${ }^{121}$ Credentials Plus sued its one-third owner and former manager, Jill Calderone, for breach of fiduciary duty and intentional interference with business relations after she began soliciting the customers of Credentials Plus for her own company, National Credentials Corporation. ${ }^{122}$ The defendant had managed the LLC, which assembled credentials-related data for physicians in client practice groups, but left to pursue her own business interests following a dispute with one of the other LLC owners that involved allegations of sexual harassment. ${ }^{123}$

The Indiana District Court granted the plaintiff's motion for summary judgment, holding that the defendant had breached her fiduciary duties to the LLC. ${ }^{124}$ The court cited the defendant's correspondence with physician groups as evidence that she had engaged in self-dealing and had breached her duty of loyalty by soliciting clients and asking them not to mention her new company to the other owners of Credentials Plus. ${ }^{125}$ In making its determination, the court relied heavily on the application of well-established fiduciary duties among partners. The traditional partnership-like language used by Indiana's LLC statute, reminiscent of the statutory language in Fine,

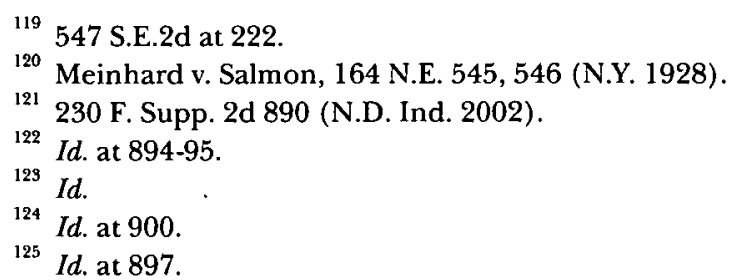


requires that " $[u]$ nless otherwise provided in a written operating agreement, each member and manager must account to the [LLC] and hold as trustee for it any profit or benefit derived by the manager or member without the consent of a majority of the disinterested managers or members." ${ }^{126}$ After noting that Indiana courts have treated closely held corporations as incorporated partnerships, the court indicated that shareholder/partners owe a fiduciary duty to deal fairly not only with the corporation, but also with other shareholders, and that they may not appropriate a business opportunity that belongs to the corporation. ${ }^{127}$

Along similar lines, in Anest v. Audino, the Illinois Appellate Court reversed the original determination by the trial court that the plaintiff, Bill Anest, did not owe a fiduciary duty to the defendant, David Audino. ${ }^{128}$ Employing the corporate opportunity doctrine, the appellate court held that, as a coinvestor in the LLC, Anest did, in fact, owe a fiduciary duty to the defendant and had breached this duty when he failed to properly tender a business opportunity to develop an exclusive distributorship. ${ }^{129}$

Anest initially became a member of Precision Pour, LLC, because he was a creditor of Audino, who had been one of three owners of the LLC. ${ }^{130}$ Following a recapitalization, Anest and the other LLC members, except for Audino, decided to form a new LLC to exercise an exclusive distributorship that initially had been offered to Precision Pour. The decision to form the new LLC without the defendant was made following an emergency meeting that had been called hastily in violation of the company's five-day notice requirement. ${ }^{131}$ Defendant Audino counterclaimed that Anest owed and had breached a fiduciary duty to him. ${ }^{132}$ At the time, the Illinois LLC statute did not contain an

${ }^{126}$ IND. CODE ANN. § 23-18-4-2(b) (West 1994).

${ }^{127}$ Credentials Plus, 230 F. Supp. 2d at 899 (citing Melrose v. Capitol City Motor Lodge, Inc., 705 N.E.2d 985, 990-91 (Ind. 1998); McLinden v. Coco, 765 N.E.2d 606, 615 (Ind. Ct. App. 2002)).

${ }^{128} 773$ N.E.2d 202, 211 (Ill. App. Ct. 2002), appeal denied, 787 N.E.2d 154 (Ill. 2002).

${ }^{129}$ Id. at 209-11.

130 Id. at 205.

${ }^{131} I d$. at 206-07. Precision Pour's operating agreement required five days notice, unless unanimous consent was given to waive it. The notice faxed to the defendant's attorney stated that the meeting was necessary to discuss restructuring the company's business from that of a nonexclusive distributorship to an importer and the effects of this change. At the meeting itself, a call was made to Audino's attorney who stated that Audino would not attend the meeting. Id.

${ }^{132}$ Id. at 207. 
express standard of care or loyalty, but provided that members and managers of LLCs would be liable to the extent that corporate shareholders or managers would be liable. ${ }^{133}$ The appellate court observed that member-managers of an LLC, like corporate directors, owe a duty to deal openly and honestly with each other and to exercise the utmost good faith and honesty. ${ }^{134}$ The court emphasized that, under Illinois law, directors and officers owe each other fiduciary duties similar to those of partners in a partnership. ${ }^{195}$

Thus, outside Delaware, the courts have been applying a mixture of partnership and/or corporate fiduciary duties to rein in opportunistic conduct, whether involving unilateral transfers of LLC property, seizure of LLC opportunities, or competitive conduct tantamount to theft of the LLC business.

\section{JUDICIAL MONITORING OF LLC FIDUCIARY DUTIES IN DELAWARE}

The Delaware LLC statute itself contains no express duty of care or duty of loyalty ${ }^{136}$ and, in fact, includes very strong statements endorsing the policy of freedom of contract and the ability to enlarge or limit various duties. ${ }^{137}$

Not surprisingly, the Delaware LLC cases that have emerged do not impose heightened fiduciary duties upon closely held enterprises. In light of the permissive tone of Delaware's LLC statute, one may wonder whether mandatory minimum duties exist and whether Delaware's contractarian approach can effectively police predatory and opportunistic conduct.

${ }^{133}$ See id. at 209-10 (explaining that, effective January 1, 1998, the Illinois LLC statute was amended to provide "that members in a member-managed [LLC] owe to each other the fiduciary duties of loyalty and care").

${ }^{134}$ Id. at 209-10.

${ }^{135}$ At the relevant time, there was no direct statutory provision regarding fiduciary duties. See 805 ILl. CoMP. STAT. 180/10-10(b) (West Supp. 2003) (providing that a manager of an LLC shall be personally liable for any act, debt, obligation, or liability of the LLC or another manager or member to the extent that a director of an Illinois business corporation has liability in analogous circumstances under Illinois law). A subsequent statutory amendment, codified at 805 ILL. COMP. STAT. 180/15-3 (West Supp. 2003), ensured that in a member-managed LLC members would owe each other the fiduciary duties of loyalty and care.

${ }^{136}$ BISHOP \& KLEINBERGER, supra note 7, II 14-98 to -99 (indicating that the Delaware statute is devoid of express statutory standards for the duty of care and duty of loyalty).

${ }^{137}$ Del. Code ANN. tit. 6, § 18-1101 (b), (c) (2) (1999 \& Supp. 2002). 
Several recent cases lend support to the view that such a mandatory minimum of acceptable conduct is unfolding in order to govern LLC managers or members. Behavioral restraints appear to be developing through three approaches: (1) the imposition of restrictions on the scope of permitted waivers of traditional fiduciary duties arising in Delaware limited partnerships; (2) the rigorous application of the entire fairness standard, which requires managers to prove a fair process and a fair price in the face of self-interested conduct; and (3) the application of contractually rooted concepts of good faith.

\section{A. Narrowing the Permissible Scope of Contractual Waivers of Fiduciary Duties}

The Delaware LLC statute contains an express statement establishing the preeminence of the contract between the parties. In particular, it declares its policy to "give the maximum effect to the principle of freedom of contract and to the enforceability of limited liability company agreements .... The member's or manager's or other person's duties and liabilities may be expanded or restricted by provisions in the limited liability company agreement." ${ }^{138}$

Virtually identical language deferring to the parties' contract is found under Delaware's Revised Uniform Limited Partnership Act (DRULPA). ${ }^{139}$ Indeed, considering that so much of the Delaware LLC statute was taken almost verbatim from DRULPA, one can expect that precedents involving Delaware's limited partnership arena will be of particular relevance in resolving LLC disputes. ${ }^{140}$

Some Delaware decisions have been so deferential to the parties' contracts that they create an impression that general partners and LLC members may substantially and materially restrict common law

${ }^{138}$ Id.

139 See id. $\$ 17-1101$ (c) (providing that "[i]t is the policy of this chapter to give maximum effect to the principle of freedom of contract and to the enforceability of partnership agreements"); see also Elf Atochem N. Am., Inc. v. Jaffari, 727 A.2d 286, 291-92 (Del. 1999) (holding, in a derivative suit on an LLC's behalf, that the LLC agreement was subject to a forum selection clause and an arbitration clause notwithstanding the fact that a derivative claim was filed and also stressing that the LLC Act's basic approach is similar to that applicable to limited partners and that both Acts permit partners to have the broadest possible discretion in drafting their agreements).

${ }^{140}$ See BISHOP \& KLEINBERGER, supra note 7, II 14-101 (observing the almost verbatim language that can be traced from the Delaware Limited Partnership statute to the Delaware LLC statute). 
fiduciary duties. ${ }^{141}$ In Sonet $v$. Timber Co., ${ }^{142}$ for instance, the Delaware Chancery Court noted that DRULPA "apparently [allows] broad license to enhance, reform, or even eliminate fiduciary duty protections. ${ }^{149}$ In Walker v. Resource Development Co. Ltd., L.L.C., ${ }^{144}$ the Delaware Chancery Court reiterated Delaware's deference to the parties' contracts, observing that " $[t]$ he basic approach of the Delaware Act is to provide members with broad discretion in drafting the [Operating] Agreement and to furnish default provisions when the members' agreement is silent." "145 The court further stated that "'[o]nce members exercise their contractual freedom in their limited liability company agreement, they can be virtually certain that the agreement will be enforced in accordance with its terms." "146 The Delaware Chancery Court went on to state that "LLC members' rights begin with and typically end with the Operating Agreement." 147

In light of the sweeping license this language appears to give to the contract, one might argue that it is permissible to very substantially reduce or even eliminate common law fiduciary duties in a Delaware LLC operating agreement. ${ }^{148}$ However, a recent Delaware

${ }^{141}$ The common law fiduciary duties of general partners have been regarded as similar to that of directors of a Delaware corporation. One would therefore expect that these same duties should be applicable to Delaware LLC members and managers unless they have been modified acceptably by contractual duties in the operating agreement. These common law fiduciary duties include: (1) a duty of care requiring a fiduciary to be attentive and well informed of all material facts relevant to a business decision; (2) a duty of loyalty requiring the fiduciary to act in the best interests of the business and its owners; and (3) a duty to disclose all material facts that would have a significant impact on business decisions. See Altman et al., supra note 57, at 8 (describing the common law fiduciary duties of partners).

${ }^{142} 722$ A.2d 319 (Del. Ch. 1998).

${ }^{143}$ Id. at 323; see also David Rosenberg, The Two Cycles of Venture Capital, $28 \mathrm{~J}$. CoRP. L. 419, 432-33 (2003) (observing that contractual flexibility is one explanation why Delaware is attractive for limited partnerships and indicating that courts "will always defer to the duties embodied in the contract itself" when the parties clearly intended to displace default fiduciary duties).

144791 A.2d 799 (Del. Ch. 2000).

${ }^{145}$ Id. at 813 (quoting Elf Atochem N. Am., Inc. v. Jaffari, 727 A.2d 286, 291 (Del. 1999)) (alteration in original).

${ }^{146}$ Id. (quoting R.F. BalotTi \& J.A. Finkelstein, THE Delaware LaW of CoRPORATIONS AND BUSINESS ORGANIZATIONS $§ 20.4(2000)$ ).

147 Id.

148 See BISHOP \& KLEINBERGER, supra note 7, I 14-96 (raising the question of whether fiduciary duties exist under Delaware LLC law). But see Altman et al., supra note 57, at 9-10 (indicating that contractual rights and duties may only preempt common law duties if they create an irreconcilable conflict and are set forth clearly and unambiguously). Altman et al. cite R.S.M. Inc. v. Alliance Capital Management Holdings, 790 A.2d 478 (Del. Ch. 2001), which involved a challenged reorganization of a publicly 
Supreme Court opinion, Gotham Partners v. Hallwood Realty Partners, ${ }^{149}$ indicates that while a partner's fiduciary duties may be restricted, they may not be completely eliminated. ${ }^{150}$ Also, in Walker v. Resource Development Co., L.L.C., ${ }^{151}$ notwithstanding the broad language on the important role of the operating agreement, the chancery court stated that Delaware's LLC provision allowing members of an LLC to rely in good faith on the terms of the operating agreement was never intended to allow the members of an LLC to misappropriate property from another member and avoid returning that property or otherwise compensating the wronged member. ${ }^{152}$

In Gotham Partners, the Delaware Supreme Court had not been asked to opine on whether a contract could eliminate common law fiduciary duties. ${ }^{153}$ The Delaware Chancery Court had granted summary judgment, holding that the defendants had violated their contractual duties in connection with a tender offer. The only issue on appeal focused on damages. Nevertheless, the Delaware Supreme Court went out of its way to correct dicta in the chancery court

traded partnership. In that case, the chancery court held that since common law fiduciary duties did not irreconcilably conflict with the contractual rights and expectations, common law fiduciary duties were not supplanted, even though the agreement did not expressly provide for this. Id. at 497-98. The authors also cited Miller $v$. American Real Estate Partners, No. 16788, slip op. at 20-21 (Del. Ch. 2001), available at http://webman. widener.edu/documents/opinions/16788-044.pdf, which indicated that restrictions on fiduciary duties must be set forth clearly and unambiguously.

149817 A.2d 160 (Del. 2002).

${ }^{150}$ Gotham Partners involved plaintiffs who were limited partners and who challenged a series of transactions that had placed the limited partnership under the control of the general partner's corporate parent at an unfair price. Id. at 164-65. The Delaware Chancery Court upheld the contractual fiduciary duty claims but dismissed the traditional fiduciary duty claims on the grounds that any common law duties had been supplanted by the contractual agreement. Gotham Partners v. Hallwood Realty Partners, No. 15754, 2000 Del. Ch. LEXIS 146, at *40 (Del. Ch. Sept. 27, 2000). Although the plaintiffs were awarded money damages, they contested the remedy offered by the Chancery Court. Gotham Partners, 817 A.2d at 170-73. The Delaware Supreme Court affirmed the chancery court's ruling that the general partner had violated its contractual standard of fairness and partially affirmed the lower court's decision with regard to damages. Id. at 178. However, the Delaware Supreme Court stated in dicta that nothing in the Delaware Revised Limited Partnership Act or elsewhere allows a limited partnership agreement to eliminate the fiduciary duties of a general partner. Id. at $167-68$.

151791 A.2d 799 (Del. Ch. 2000).

${ }^{152} I d$. at 813-15 (addressing the question of whether the members of a majority in interest of a Delaware LLC could remove the plaintiff as a member of the LLC and declare his interest in the LLC forfeited and holding that, unless expressly granted a power of removal by contract, the majority of the members or stockholders of a business entity have no right to take the property of other members).

${ }^{153}$ Gotham Partners, 817 A.2d at 160. 
opinion which had stated that DRULPA expressly authorized the elimination, modification, or enhancement of fiduciary duties. ${ }^{154}$ The Delaware Supreme Court observed that this erroneous dicta could be misinterpreted in future cases as a correct rule of law. ${ }^{155}$ It went on to admonish courts, commentators, and practitioners:

[W] e are constrained to draw attention to the statutory language and the underlying general principle in our jurisprudence that scrupulous adherence to fiduciary duties is normally expected.

Section 17-1101(d) (2) states: "the partner's or other person's duties and liabilities may be expanded or restricted by the provisions in the partnership agreement." There is no mention ... that a limited partnership agreement may eliminate the fiduciary duties or liabilities of a general partner. ${ }^{156}$

Questions of the scope of acceptable contractual waivers of fiduciary duties in Delaware have also been raised in the context of a takeover of a corporation. In Omnicare, Inc. v. NCS Healthcare, Inc., ${ }^{157}$ the Delaware Supreme Court was required to determine whether the directors of an insolvent corporation, NCS, had violated their fiduciary duties by approving a merger transaction. The merger agreement obligated the directors to bring the merger proposal to a shareholder vote even if the directors failed to approve it; restricted the directors' rights to consider other merger agreements; required two of the directors, who were also sixty-five percent owners of the target, to vote in favor of the merger; and established appraisal rights for minority owners. ${ }^{158}$ The case is significant both because the Delaware Supreme

${ }^{154}$ Id. at 167-68; see also Gotham Partners, 2000 Del. Ch. LEXIS 146, at *34 (construing DRULPA to permit the elimination of partners' fiduciary duties).

${ }^{155}$ Cotham Partners, 817 A.2d at 167.

${ }^{156} I d$. at 167-68 (emphasis added) (quoting DEL. CODE ANN. tit. 6, § 17-1101(d) (2) (1999)).

${ }^{157} 818$ A.2d 914, 936 (Del. 2003).

${ }^{158}$ Id. at $925-26$. The directors of NCS approved the terms of a merger with Genesis, a publicly traded Pennsylvania company that promised to pay off all of NCS's creditors and to replace NCS shares with its own. Id. at 919, 924-25. Genesis insisted on the restrictive clauses. In addition, it gave the four-member NCS board of directors less than twenty-four hours in which to approve the merger agreement and gave the two board members who collectively owned sixty-five percent of the stock the same accelerated timetable for signing the related voting agreements. Id. at 925. NCS shareholders sued to enjoin the Genesis merger and for breach of fiduciary duties. Id. at 919. The Delaware Chancery Court initially held that the board's defensive measures were reasonable. Id. at 934. In a rare 3-2 split, Delaware Supreme Court reversed, observing that the NCS board was required to contract for an effective fiduciary out clause to exercise its continuing fiduciary responsibility to its minority stockholders. Id. at 936-37. The voting agreements and the defensive measures in the merger 
Court employed enhanced judicial scrutiny and because it subordinated the parties' contractual expectations to the overriding policy interest in having directors properly discharge their fiduciary duties. ${ }^{159}$ As the court observed:

In the context of this preclusive and coercive lock up case, the protection of Genesis' contractual expectations must yield to the supervening responsibility of the directors to discharge their fiduciary duties on a continuing basis. The merger agreement and voting agreements, as they were combined to operate in concert in this case, are inconsistent with the NCS directors' fiduciary duties. To that extent, we hold that they are invalid and unenforceable. ${ }^{160}$

Although the Omnicare holding is limited to the context of coercive measures in connection with the merger of a public company, it has significance to all business entities insofar as it reveals the Delaware Supreme Court's willingness to place limitations on the extent to which directors may contract away their fiduciary duties in private agreements.

Based on the principles enunciated in Gotham and Omnicare, and the similarity between Delaware's limited partnership and LLC statutes, one would expect that the Delaware Supreme Court will not permit a broad and/or complete elimination of fiduciary duties in the LLC. Although the court has not yet addressed this issue, the Delaware LLC cases that have emerged do reflect an active judicial posture.

In Solar Cells, Inc. v. True North Partners, $L L C,{ }^{161}$ for example, the Delaware Chancery Court ultimately enjoined a clandestine attempt to merge First Solar, LLC, into defendant's wholly owned subsidiary. ${ }^{162}$ The defendant, True North Partners, LLC, controlled three of First Solar's five managers, while the plaintiff, Solar Cells, Inc., appointed the other two. ${ }^{163}$ These latter two managers were not advised of the

agreement were regarded as being inextricably combined and as requiring enhanced judicial scrutiny. Id. at 934. Employing the two-part test established in Unocal Corp. $v$. Mesa Petroleum Co., 493 A.2d 946 (Del. 1985), the court stated that the NCS directors had to establish that they had reasonable grounds for believing that a danger to corporate policy and effectiveness existed and that that their defensive response was reasonable in relation to the threat posed. Omnicare, $818 \mathrm{~A} .2 \mathrm{~d}$ at 935 . After analyzing each provision, the court held that the defensive measures had failed to fall within the range of reasonableness. Id. at 936 .

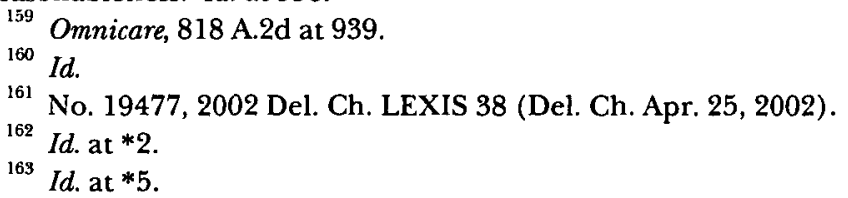


proposed merger until shortly before it was to close. ${ }^{164}$ Although a full board meeting was held the day before the three True North managers gave their written consent to the merger, the three failed to inform the other two board members of the merger. ${ }^{165}$ If consummated, the merger would have had the effect of diluting the plaintiff's interest from a fifty percent interest to a five percent interest. ${ }^{166}$ The True North managers defended their actions based on the contractual limitation of their fiduciary duties. ${ }^{167}$ Nevertheless, while the operating agreement of First Solar did contain a fairly broad waiver of conflicts of interests, the court latched onto the fact that it had not eliminated the duty to act in good faith. ${ }^{168}$ As a result, the court ultimately enjoined the merger. Had the court more broadly interpreted the waiver clause, however, a different decision might have been reached.

\section{B. Minimum Standards Flowing From the Evidentiary Burden of Establishing Entire Fairmess}

A potential source of minimum standards of acceptable LLC manager conduct in Delaware may well emerge through the evidentiary burden of requiring LLC managers to prove that a self-interested transaction was fundamentally fair.

In Solar Cells and in VGS, Inc. v. Castiel, ${ }^{169}$ another LLC merger case, the mergers were successfully challenged on the grounds that the managers' conduct was self-interested and the defendants would not be able to meet the burden of establishing that the mergers were fundamentally fair. ${ }^{170}$

Normally, in Delaware the business judgment rule provides that a director is presumed to act on an informed basis, in good faith, and in the best interests of the company. ${ }^{171}$ The evidentiary burden is initially

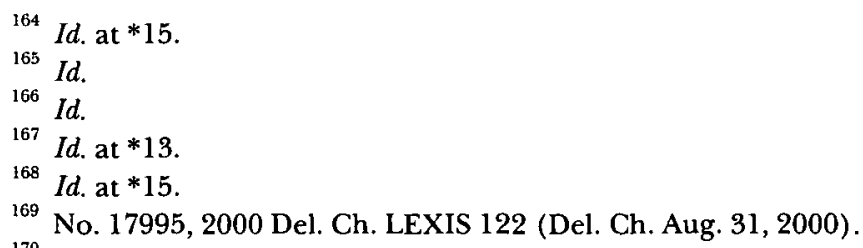

170 Solar Cells, 2002 Del. Ch. LEXIS 38, at *22 ("Solar Cells has demonstrated a reasonable likelihood of success on the merits of its entire fairness claim ...."); VGS, 2000 Del. Ch. LEXIS 122, at*14-17 (holding that the managers' secret attempt to obtain control of the LLC violated their duty of loyalty).

${ }^{171}$ See Aronson v. Lewis, 473 A.2d 805, 812 (Del. 1984) (indicating that the business judgment rule "is a presumption that in making a business decision the directors of a corporation acted on an informed basis, in good faith and in the honest belief that the action taken was in the best interests of the company"); see also Unocal Corp. v. 
placed on the plaintiff to rebut this presumption. ${ }^{172}$ If and when the presumption is rebutted, the directors' conduct is examined under the entire fairness standard, whereby the court scrutinizes the fairness of the process and the fairness of the price. ${ }^{173}$

Since the presumption of the business judgment rule presupposes that there has been an independent, disinterested decision maker, it does not apply where a director has a conflict of interests. ${ }^{174}$ Where a director is tainted by self interest, the presumption of the business judgment rule is inapplicable and the burden of proof is effectively placed upon the defendant. The court becomes the "objective arbiter," 175 and the self-interested director must demonstrate that her conduct has been fair, which entails an analysis of whether the transaction was undertaken in a fair process and at a fair price. ${ }^{176}$

It has been through this analysis of fundamental fairness that plaintiffs have received protection from opportunistic conduct in connection with mergers. In VGS Inc. v. Castiel, ${ }^{177}$ the Delaware Chancery Court held that two of three board members had breached their duty of loyalty to the plaintiff. ${ }^{178}$ The two board directors had failed to notify the plaintiff of the proposed merger, which had the effect of

Mesa Petroleum Co., 493 A.2d 946, 958 (Del. 1985) (stating that "unless it is shown ... that the directors' decisions were primarily based on perpetuating themselves in office, or some other breach of fiduciary duty ... a Court will not substitute its judgment for that of the board"); Sinclair Oil Corp. v. Levien, 280 A.2d 717, 720 (Del. 1971) (noting that the business judgment will be upheld if there is any rational business purpose).

${ }^{172}$ Cinerama, Inc. v. Technicolor, Inc., 663 A.2d 1156, 1162 (Del. 1995).

173 Id. at $1162-63$.

${ }^{174}$ See Nixon v. Blackwell, 626 A.2d 1366, 1376 (Del. 1993) ("In business judgment rule cases, an essential element is the fact that there has been a business decision made by a disinterested and independent corporate decisionmaker. When there is no independent decisionmaker, the court may become the objective arbiter." (citations omitted)).

${ }_{175}$ Id.

${ }^{176}$ See Weinberger v. UOP, Inc., 457 A.2d 701, 710-11 (Del. 1983) (holding that a director with a conflict of interest must show the entire fairness of the transaction, which incorporates the concepts of fair dealing and fair price); see also Nixon, 626 A.2d at 1376 (holding that an entire fairness analysis is required when there is no independent corporate decision maker).

${ }^{177}$ No. 17995, 2000 Del. Ch. LEXIS 122 (Del. Ch. Aug. 31, 2000), aff'd 781 A.2d 696 (Del. 2001).

${ }_{178}$ Id. at *14; see also VGS, Inc. v. Castiel, No. 17995, 2003 Del. Ch. LEXIS 16, at *40, *51 (Del. Ch. Mar. 10, 2003) (holding that the defendant directors had breached their duty of loyalty to Castiel when they secretively consented to merge Virtual Geo into VGS, Inc. without informing him), reargument granted, 2003 Del. Ch. LEXIS 31 (Del. Ch. Mar. 27, 2003). 
divesting the plaintiff of majority control of the business. ${ }^{179}$ Because the directors were on both sides of the transaction, they had to establish that the merger was accomplished in a fair process and at a fair price. They failed to do so and the merger was enjoined. ${ }^{180}$

Similarly, in Solar Cells, mentioned above, the Delaware Chancery Court enjoined a merger at the request of an LLC member. ${ }^{181}$ The court believed that the waiver of conflicts of interest did not extinguish all fiduciary duties. ${ }^{182}$ In deciding the motion for preliminary injunction, the court determined that the defendants would be asked to prove the entire fairness of the merger. ${ }^{183}$ Under this standard, it was unlikely that the defendants could establish that the merger was the product of fair dealing and that it offered a fair price. ${ }^{184}$

Thus, as illustrated in both VGS and Solar Cells, express squeezeout strategies have been combated in Delaware through a rigorous application of the entire fairness test.

\section{Resourceful Use of Contractually Based Standards to Build a Mandatory Core in Delaware}

Restraints growing out of traditional contract law doctrines can serve as yet another potential source of restraint against predatory and opportunistic conduct by LLC members and/or managers. In Delaware, for example, the contractually based concept of "good faith" has the potential to become an important means of establishing a mandatory minimum for acceptable LLC manager and/or member conduct.

Many scholars have distinguished the fiduciary obligation from the contractual standard of good faith. Professor Deborah A. DeMott, for instance, has observed that the fiduciary obligation rests on the notion that the beneficiary is vulnerable to the exercise of the fiduciary's abuse of power, whereas the contractual standard proceeds on the assumption that the parties stand on a relatively level playing field and are bargaining at arms length. ${ }^{185}$ She further points out that the

179 VGS, 2000 Del. Ch. LEXIS 122, at *5.

${ }^{180}$ Id. at *2.

181 Solar Cells, Inc. v. True N. Partners, LLC, No. 19477, 2002 Del. Ch. LEXIS 38, at *26-27 (Del. Ch. Apr. 25, 2002).

${ }^{182}$ Id. at $* 15$.

${ }^{189} I d$. at $* 16$.

184 Id. at $* 20$.

185 See Deborah A. DeMott, Beyond Metaphor: An Analysis of Fiduciary Obligation, 1988 DuKE L.J. 879, 902 (suggesting that fiduciary obligations are often justified by the fact that a party is vulnerable to a fiduciary's abuse of power, whereas contract law 
standard of good faith looks to how the parties actually perform the obligations in the contractual agreement, cannot be disclaimed, and does not prohibit self-interested conduct. ${ }^{186}$ In contrast, the fiduciary obligation broadly commits the fiduciary to exercise discretion in the interests of the beneficiary, ${ }^{187}$ generally prohibits self-interested conduct, ${ }^{188}$ but may be susceptible to being limited. ${ }^{189}$

While academicians visualize the standard of good faith as residing on a significantly lower plane than that occupied by the fiduciary duty of loyalty, ${ }^{190}$ the contractual obligation of good faith may nevertheless be an important mechanism through which the courts can police abusive conduct in the LLC context. For example, the standard of good faith was useful to justify enjoining the clandestine merger in Solar Cells, discussed above. ${ }^{191}$ A contractual waiver of conflicts of interest was not interpreted as a waiver of all fiduciary duties, and the court observed that the operating agreement itself expressly contained a requirement that the managers act in good faith. ${ }^{192}$ The court then proceeded to state that the defendant's actions did not appear to be those of fiduciaries acting in good faith. ${ }^{193}$ The court believed that the defendants would be required to show the entire fairness of the proposed merger and did not believe they would be able to

often presupposes free bargaining power of parties on equal social and economic footings).

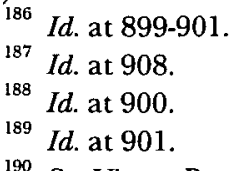

${ }^{190}$ See Victor Brudney, Contract and Fiduciary Duty in Comporate Law, 38 B.C. L. REV. $595,624-25$ (1997) (indicating that "the fiduciary must act for the beneficiary's exclusive benefit," while the classic contractual relationship allows each party to act in his or her own interests); Dickerson, supra note 41, at 458-61 (discussing the actual harm that can occur when fiduciary duties are not mandatory and criticizing ULLCA for allowing the standards of performance to drop down to the level of good faith); Mitchell, supra note 82, at 1715-16 (criticizing the courts' application of fiduciary duties in the context of freeze-outs in close corporations and stressing that there has been a conceptual shift in the application of fiduciary duties from an emphasis on selfless conduct, whereby the fiduciary duty functions as a moral precept, to the pragmatic view that selfinterested conduct is permitted in the absence of the fiduciary's malfeasance); $D$. Gordon Smith, The Critical Resource Theory of Fiduciary Duty, 55 VAND. L. REv. 1399, 1485-86 (2002) (asserting that the recent trend in partnership law, epitomized by the Revised Uniform Partnership Act, is to displace fiduciary duties with narrower contractual standards).

191 Supra note 168 and accompanying text.

${ }^{192}$ Solar Cells, Inc. v. True N. Partners, LLC, No. 19477, 2002 Del. Ch. LEXIS 38, at *15 (Del. Ch. Apr. 25, 2002).

Id. at *15-16. 
sustain their burden of proof. ${ }^{194}$ Therefore, the merger was enjoined. ${ }^{1.5}$

The court did not distinguish between good faith as an express contractual standard and good faith in a fiduciary sense. Whether meant in a contractual or fiduciary sense, the apparent bad faith of the defendants' conduct led to the finding that the predatory conduct should be enjoined.

\section{A COMMON THREAD OF MANDATORY DUTIES OUTSIDE AND INSIDE DELAWARE LLCS}

The above discussion examines several decisions outside of Delaware that apply traditional concepts of partnership and/or corporate fiduciary duties to combat patterns of misconduct now emerging in the LLC. Despite mounting criticism, ${ }^{196}$ these hardy fiduciary constructs successfully combated the majority's seizure of LLC real estate in Fine ${ }^{197}$ and capably thwarted the unilateral estate planning restructuring in Flippo. ${ }^{198}$ As the workhorse and backbone of business entity law, fiduciary constraints were well suited to attack a manager's usurpation of the LLC's business in Credentials Plus, ${ }^{199}$ and were effective in preventing the clandestine formation of a new company that would exclude the minority in Anest. ${ }^{200}$ Would Delaware's approach of scrutinizing self-interested conduct through the entire fairness test have achieved similar results, and if so, does it matter which approach is taken?

It could be argued that the entire fairness test would have produced similar results in Fine, for example, in which the managing owner essentially stole the LLC's real estate. It could have been argued that the defendant stood on both sides of the transaction and that the transaction lacked entire fairness. The same could have been said for the restructuring in Flippo and the clandestine, exclusionary

194 Id. at $* 20$.

195 Id. at $* 27$

196 See Banoff, supra note 49 , at 69 (indicating that fiduciary duties are regarded in some circles as the "f-word" to be purged from LLC legislation).

${ }^{197}$ Fine v. Bork, No. 010808586, 2002 Conn. Super. LEXIS 181 (Conn. Super. Ct. Jan. 15, 2002); supra notes 104-09 and accompanying text.

${ }^{198}$ Flippo v. CSC Assocs. III, 547 S.E.2d 216 (Va. 2001); supra notes 111-19 and accompanying text.

${ }^{199}$ Credentials Plus, L.L.C. v. Calderone, 230 F. Supp. 2d 890 (N.D. Ind. 2002); supra notes 121-27 and accompanying text.

${ }^{200}$ Anest v. Audino, 773 N.E.2d 202, 211 (Ill. App. Ct. 2002), appeal denied, 787 N.E.2d 154 (Ill. 2002); supra notes 128-35 and accompanying text. 
merger in Anest. In addition, a contractarian-minded court could have reached a similar result in Credentials Plus by using the contractually oriented standard of good faith.

Regardless of the specific legal doctrine used to combat opportunism, courts both outside and inside of Delaware are signaling that one is expected to behave in a trustworthy manner. Even within the context of a business entity governed by a private contract, the essential message is that there are social constraints and social responsibilities to others. At first blush, the broad policy statements exalting the freedom of contract in Delaware may create the impression of an LLC landscape without limits, but the recent statements by the Delaware Supreme Court in both partnership and corporate contexts, the application of the entire fairness test, and the concept of "good faith" illustrate that, within the contractarian environment, there is indeed a mandatory core of acceptable business conduct. However, the specific contours of fiduciary duties owed in Delaware LLCs have yet to be fully defined. Because Delaware does not recognize heightened fiduciary duties in close corporations, a valid concern is that the fiduciary protections in the context of the Delaware LLC might be narrow, stemming primarily either from contract or from the entire fairness test.

Many factors may make it more effective to curb opportunistic LLC conduct through a broad formulation of fiduciary duties than through contractual limitations or through a more focused scrutiny of self-interested conduct using the entire fairness test. A narrower contract-oriented approach to fiduciary duties may inappropriately serve the interests of the more affluent and may be unrealistic in terms of the practical usage of the LLC by certain members of the business community. Also, an expansive view of fiduciary duties may be preferable to a narrower approach if that better reflects positive ethical norms in the business community. Finally, a broader approach to fiduciary duties may be a more effective legal doctrine than a narrower conception of entire fairness in policing subtle freeze-outs.

In terms of the practical usage of the LLC, it is evident that some investors may be quite casual about drafting LLC agreements and, indeed, may not even have LLC operating agreements. ${ }^{201}$ Others may simply select a form agreement themselves, in the interest of keeping

${ }^{201}$ See, e.g., New Horizons Supply Co-op. v. Haack, 590 N.W.2d 282 (Wis. Ct. App. 1999) (unpublished table decision) (indicating that an LLC agreement was never entered into evidence), available at 1999 Wis. App. LEXIS 108, at*3. 
down organizational costs. ${ }^{202}$ As a result, the contractarian approach of relying on contractual provisions to protect against opportunistic conduct may be more well suited to big business than to the work-aday world of small business. The general partner of a real estate investment is likely to be represented by a national law firm. She may have engaged highly sophisticated attorneys and be in a position to tailor-make contracts. However, small business entities present an entirely different picture. The law should serve the needs of the full business community, including those with fewer financial resources who nevertheless make up an important sector of our economy. ${ }^{203}$ While the attorney representing the real estate syndicator may well prefer a minimalist judicial posture, this preference may work at a distinct disadvantage to the smaller, less-sophisticated business owner whose legal counsel may be a general practitioner without a great deal of specialization in the nuances of LLC operating agreements. In a less-than-perfect world of private ordering, a balanced approach to fiduciary duties may be called for, which may necessitate judicial discretion.

A traditional endorsement of fiduciary duties may be preferable to a narrower, contract-oriented approach insofar as it sends a message to the business community that appropriate social behavior requires an entity and the individuals who compose it to conduct themselves in a trustworthy and honest manner, which means considering first and foremost, the welfare of the collective business unit rather than one's self-interest. ${ }^{204} \mathrm{~A}$ broader statement of duties may better reflect society's norms of ethical behavior than a narrower formulation of

${ }^{202}$ See, e.g., W. DEAN Brown, How to Form a Corporation, LlC OR PartNERSHIP IN PENNSYLVANIA (2000) (compiling forms, certificates, and easy-to-follow instructions on the formation of business entities in Pennsylvania); SCOTT E. FRIEDMAN, HOW TO PROFIT BY FORMING YOUR OWN LIMITED LIABILITY COMPANY (1996) (detailing how to form, manage, and dissolve LLCs and including sample forms and a comparison of legal entities); MARTin M. Shenkman et al., Starting a Limited Liability COMPANY (1996) (providing a guide on how to establish an LLC).

${ }^{203}$ See U.S. CENSUS BUREAU, STATISTICS OF U.S. BUSINESS: 2000: ALL INDUSTRIES UNITED STATES (indicating that out of 5,652,544 total firms, 726,862 had no employees, 2,669,870 firms had one to four employees, and 1,021,210 had five to nine employees), available at http://www.census.gov/epcd/susb/2000/us/US-HTM (last modified Dec. 15, 2003); see also Press Release, Patricia Buscher, U.S. Census Bureau, 'Mom-and-Pop' Shops Increase (Oct. 22, 2002) (stating that "[b] usinesses with no paid employees grew 2.3 percent between 1999 and 2000 from 16.2 million to 16.5 million"), available at http://www.census.gov/Press-Release/www/2002/cb02-138.html.

${ }^{204}$ Blair \& Stout, supra note 24, at 1738-43. 
responsibilities. ${ }^{205}$ On the other hand, if fiduciary duties are articulated in a manner that is overly broad and unduly protective of the minority, majority owners may be deterred from investing in enterprises with minority owners. Thus, the judicial and statutory legal environment must strive for a balanced approach that considers the interests of the majority as well as the interests of the minority. ${ }^{206}$

The entire fairness approach, entailing a fair price and fair process, may gloss over the nature and scope of damages and required remedies in the context of a small, owner-managed business enterprise. A fairness analysis may thus overlook the actual injuries sustained in a private business. As Professor Douglas K. Moll has articulated in his investment model of the corporation, the owner's entire investment in the firm must be considered, including the interest the owner has in employment, her work product, and her customer base. ${ }^{207}$ In a privately owned business, the entrepreneur's investment in the business entity has tangible and intangible components. Fundamentally fair conduct, consisting of a buyout pursuant to a fair process and at a fair price, may not make one whole when one's interests in the enterprise are more complex, partly intangible, and/or nonmonetary. Thus, a broader and more flexible judicial approach may be necessary to properly identify the injuries in the context of the private business entity.

Also, on a practical level, the entire faimess test may not prove adequate to combat all types of freeze-outs and squeeze-outs that occur in a small, private business. As discussed by Professor Robert A. Ragazzo in the context of corporate squeeze-outs, the entire fairness test may be effective against overt freeze-outs, but may be difficult to apply to more subtle patterns of abuse in the LLC, such as failures to make distributions to the minority. ${ }^{208}$ In private entities, decisions

205 See generally Symposium, Norms and Comporate Law, 149 U. PA. L. REV. 1607 (2001) (exploring the role of norms in influencing human behavior); see also Timothy L. Fort, Goldilocks and Business Ethics: A Paradigm that Fits "Just Right," 23 J. CORP. L. $245,247-48,263-65$ (1998) (analyzing the structure of corporations as mediating institutions to promote ethical behavior necessary for moral development).

${ }^{206}$ See Weidner, supra note 37, at 103-04 (advocating a balanced policy of partnership relationships and observing that the cost of eliminating mandatory minima is the cost of authorizing lawlessness in business relationships).

${ }^{207}$ Douglas K. Moll, Shareholder Oppression v. Employment at Will in the Close Corporation: The Investment Model Solution, 1999 U. ILL. L. REV. 517, 520 (recognizing that there may be many components to a shareholder's investment in a corporation).

${ }^{208}$ See Ragazzo, supra note 86, at 1142-47, 1151 (acknowledging the possibility that the entire fairness test might not effectively prevent subtle freeze-out schemes in closely held corporations but indicating that the only obstacle would be in defining the 
concerning salaries, distributions, hiring, and firing could be tainted by self-interest. To be an effective tool in the private business setting, the entire fairness test might need extensive triggers. ${ }^{209}$

\section{ADJUSTING THE CONTRACTARIAN MODEL TO ACCEPT PRIVATE ORDERING WITH A MANDATORY MINIMUM: THE ROLE OF THE COURT}

The comparative analysis of the developing case law outside and inside Delaware, which is presented in Part IV, reveals the need to reevaluate the LLC's contractarian model. The contractarian paradigm is widely perceived as a theory that promotes the supremacy of the contract above all other values. However, experience with the LLC, as reflected by the various cases discussed, underscores the need for judicial monitoring of this type of business relationship. Courts recognize the importance of fiduciary duties, the significant role equitable principles play in mediating LLC disputes, the value of the law in promoting ethical standards of conduct, and the need to bridge the gap between legal theory and business practice.

Although academics have placed much emphasis on the Nixon decision in Delaware, ${ }^{210}$ which failed to impose heightened fiduciary duties, less attention has been focused recently on long-standing endorsements of fiduciary duties both in other jurisdictions and in Delaware itself. It was the Delaware Supreme Court that stated in 1939:

A public policy, existing through the years, and derived from a profound knowledge of human characteristics and motives, has established a rule that demands of a corporate officer or director, peremptorily and inexorably, the most scrupulous observance of his duty, not only affirmatively to protect the interests of the corporation committed to his charge, but also to refrain from doing anything that would work injury to the corporation, or to deprive it of profit or advantage which his skill and

elements of a freeze-out (e.g., the discharge of the minority, failure to pay dividends, or preclusion of board participation) as a form of self-dealing).

${ }^{209}$ Cf. id. at 1134 (citing the flexibility of the Delaware Supreme Court regarding the rules of judicial review and the potential that, when presented with the right case, the court may reconsider its views and hold that a majority owner of a close corporation owes a fiduciary duty of fairness to the minority).

${ }^{210}$ For examples of academic work analyzing Nixon v. Blackwell, 626 A.2d 1366 (Del. 1993), see James D. Cox, Mergers and Acquisitions: Equal Treatment for Shareholders, 19 CARDOZO L. REV. 615, 616-19 (1997); Kelly, supra note 83; James M. Van Viet Jr. \& Mark D. Snider, The Evolving Fiduciary Duty Solution for Shareholders Caught in a Closely Held Corporation Trap, 18 N. ILL. U. L. REv. 239, 242 (1998). 
ability might properly bring to it, or to enable it to make in the reasonable and lawful exercise of its powers. ${ }^{211}$

Perhaps the contractarian model should acknowledge the continuing relevance of fiduciary duties, the broader social context in which private business entities exist, and the wide array of mandatory legal constraints that apply even in our landscape of private ordering.

\section{A. Recognizing the Need for Flexible Judicial Concepts Within the Contractarian Paradigm}

As previously discussed, courts will intervene in the affairs of private business when fundamental notions of fairness have been violated. Courts have been willing to adapt a variety of behavioral standards to combat self-interested opportunistic conduct, whether it consists of fundamental changes, ${ }^{212}$ unilateral asset transfers, ${ }^{213}$ or sudden meetings that squeeze out another owner's interest. ${ }^{214}$

The critical role of the judiciary and the need for flexible judicial concepts and equitable doctrines is evident in emerging LLC case law, yet both are virtually lost, conceptually, in the contractarian model because of its emphasis on contractual freedom. As London School of Economics Professor C.A.E. Goodhart observed: "[F]or the law to ignore questions of equity is rather like asking Mrs. Lincoln whether she otherwise liked the play." ${ }^{215}$ Professor Goodhart quite correctly goes on to point out that the law and economics approach seems, at times, to elevate the achievement of economic efficiency above concepts of justice and equity. ${ }^{216}$

${ }^{211}$ Guth v. Loft, Inc., 5 A.2d 503, 510 (Del. 1939).

${ }^{212}$ E.g., Fine v. Bork, No. 010808586, 2002 Conn. Super. Ct. LEXIS 181, at *6 (Jan. 16 , 2002) (involving a situation where a managing member of the LLC "took advantage of his position" and amended the operating agreement in order to appropriate a company asset for his own personal benefit).

${ }^{213}$ E.g., Flippo v. CSC Assocs. III, 547 S.E.2d 216, 219 (Va. 2001) (affirming a manager's liability for breach of fiduciary duty for conveying all of the LLC's property to a new venture).

${ }^{214}$ E.g., Anest v. Audino, 773 N.E.2d 202, 206-07 (Ill. App. Ct. 2002) (finding a breach of fiduciary duties where, without the fifth member's consent, four members formed a new entity, which did not include the fifth LLC member, to handle the LLC's business), appeal denied, 787 N.E.2d 154 (Ill. 2002).

${ }^{215}$ C.A.E. Goodhart, Economics and the Law: Too Much One-Way Traffic?, 60 MOD. L. REV. 1,12 (1997).

${ }^{216}$ See id. at 14 (discussing specific performance in the context of contract law, which requires a party to perform her obligations rather than pay more economically efficient, nonperformance damages). 
Delaware Chief Justice E. Norman Veasey has stated that "[t]he defining tension in corporate governance today is the tension between deference to directors' decisions and the scope of judicial review." ${ }^{217}$ At least with regard to private business entities, I suggest that the defining tension resides in the collision between a legislature that wants to constrain the judiciary in the interests of contractual freedom and an independent judiciary poised to promote fundamental notions of equity and fairness that every investor legitimately expects courts to protect. $^{218}$

The courts are doing their job of enforcing the private bargain while also establishing equitable protections against unduly exploitative and deceptive conduct, whether through statem.nts of fiduciary duties or by shifting the burden of proof to require a showing of fundamental fairness where the presumption of a disinterested, informed decision made in good faith has been rebutted. While some of the LLC decisions discussed above reflect discretionary judgments regarding violations of fiduciary duties, several cases illustrate judicial selfrestraint. In these latter cases, courts have been willing to deny relief in order to enforce the contract between the parties, even though the enforcement appeared, on some level, to produce an unfair result.

Where the unfair result has occurred because the plaintiff entered into a poor bargain, a number of courts have refused to fashion broad remedies that change the outcome. For example, in Lieberman $v$. Wyoming.com $L L C,{ }^{219}$ the Wyoming Supreme Court refused to order the defendants to repay more than the plaintiff's $\$ 20,000$ capital contribution. In that case, the plaintiff withdrew from the LLC and demanded the fair market value of his interest in it. ${ }^{220}$ The court, however, upheld the LLC operating agreement, which provided only for the return of capital contributions. ${ }^{221}$ Although the case was remanded for further proceedings to establish whether the plaintiff in fact retained his ownership interest and/or was entitled to be paid interest on its fair market value, ${ }^{222}$ the court failed to superimpose a solution that would have fashioned an equitable payment in settlement

${ }^{217}$ E. Norman Veasey, The Defining Tension in Corporate Governance in America, 52 BuS. LAw. 393, 403 (1997).

${ }^{218}$ See Jacobs, supra note 12, at 1044-45 (discussing the inherent tension underlying many enabling statutes between a policy that protects the legitimate expectations of investors and a policy that favors freedom of contract).

2191 P.3d 353 (Wyo. 2000).

220 Id. at 355 .

221 Id. at 359.

$222 I d$. at 361. 
of the dispute. Similarly, in Whitmore v. Hawkins, ${ }^{223}$ the Fourth Circuit refused to require the defendants to pay plaintiff the fair market value of his interest in two LLCs upon his withdrawal because the applicable LLC operating agreements expressly stated that the involuntarily withdrawn member was not entitled to the fair market value of the interest if the LLCs were continued. ${ }^{224}$ Likewise, courts have respected and enforced various other LLC operating agreements even where they have curtailed specific fiduciary duties, e.g., by permitting competition, ${ }^{225}$ by denying the right to remove a manager, ${ }^{226}$ or by providing work-in-progress payments to retiring or deceased members but not to withdrawing members. ${ }^{227}$

Although predictability and certainty are important policy goals that evolving statutory and judicial LLC law should embrace, the continuing occurrence of predatory and exploitative patterns of conduct seen in the close corporation and LLC settings illustrates the need for judicial flexibility and equitable concepts to combat conduct that violates fundamental notions of fair play.

Elastic concepts such as fiduciary duty are not out of place in a system designed to enforce contractual expectations within the business entity, but rather are the very backbone of our system of private

${ }^{223}$ No. 99-1443, 2000 U.S. App. LEXIS 14670 (4th Cir. June 27, 2000).

224 Id. at *20-23.

${ }^{225}$ McConnell v. Hunt Sports Enters., 725 N.E.2d 1193, 1210 (Ohio Ct. App. 1999) (holding that there was no breach of fiduciary duty where the LLC agreement permitted competition and the defendant successfully competed); see also Lynch Multimedia Corp. v. Carson Communications, L.L.C., 102 F. Supp. 2d 1261, 1264 (D. Kan. 2000) (holding that where an LLC agreement permitted the LLC members to engage independently or with others in other business ventures of every nature and description, a member did not violate any duties when he independently acquired a competing cable franchise).

${ }^{226}$ JTB Enters., L.C. v. D \& B Venture, L.C. (In re Deluca), 194 B.R. 79, 86-87 (Bankr. E.D. Va. 1996) (denying plaintiff's right to remove the defendant-debtor as manager of the LLC because the implication under the amended operating agreement was that the plaintiff and the defendant had equal voting rights and the plaintiff lacked the majority block needed to remove the defendant as manager).

${ }^{227}$ Goldstein \& Price, L.C. v. Tonkin \& Mondl, L.C., 974 S.W.2d 543, 550-51 (Mo. Ct. App. 1998) (reversing the trial court's award of fifty-nine percent of a fee paid to the plaintiff and substituting a thirteen percent fee payment because, although the LLC's operating agreement made no provision for awards of fees earned by withdrawing members for work in progress, the LLC members had orally amended the LLC operating agreement to pay the plaintiff thirteen percent of the fee in question upon his withdrawal). 
ordering. ${ }^{228}$ Constructs that leave room for judicial discretion, such as fiduciary duties, unconscionability, and the contractual concept of good faith, are indispensable because they enable courts to police opportunistic conduct in something resembling a fair legal environment. ${ }^{29}$

As a practical matter, the LLC judicial and statutory environment must attempt to serve the interests of clarity and predictability, as well as the policy goals of achieving fairness and safety from opportunistic conduct. "Contextualists" claim that the most important thing in a legal system is for the laws to be flexible and fair, and to avoid arbitrariness. "Neoformalists" argue that broad standards are problematic and believe that legislators should flesh out the law. ${ }^{231}$ As noted by Robert A. Hillman, both the goals of fairness and predictability are important. $^{232}$ Legislators should try to make LLC statutes clear and predictable. However, legislators should not attempt to strip the judiciary of its rightful role of reviewing each case on its facts and applying equitable principles in its decision-making process. Finally, legislators should not presume that most members of the business community have made the costly investment to execute highly negotiated organizing documents. Well-developed statutory default rules (for those without elaborate LLC operating agreements) and safety valves, such as fiduciary duties, are needed to combat opportunistic conduct that has long plagued the private business enterprise.

\section{CONCLUSION}

The emerging body of LLC case law in Delaware and other states is recognizing a mandatory core of conduct, whether described in terms of partnership and/or corporate-style fiduciary duties, good faith, or the duty to show entire fairness. In one way or another the courts are embracing a mandatory core that is essential, particularly where there are gaps in the parties' agreements or where the parties stand in unequal positions. ${ }^{238}$ These developments are positive,

${ }^{228}$ See Banoff, supra note 49, at 69-70 (analyzing Florida's revised LLC statute and observing that the statute has removed the term "fiduciary" in an apparent attempt to curb so-called "galloping Meinhardism" by the judiciary).

${ }_{229}$ ROBERT A. HILlMAN, THE RICHNESS OF CONTRACT LAW 132-46 (1997).

${ }^{230}$ Id. at 168 .

${ }^{231} I d$.

${ }^{232} I d$.

${ }^{233}$ See Claire Moore Dickerson, From Behind the Looking Glass: Good Faith, Fiduciary Duty E Permitted Harm, 22 FLA. ST. U. L. REV 955, 977-78 (1995) (supporting a view 
although too much protection could become counterproductive if courts become too solicitous of minority interests.

The developing strains of business entity governance hold the promise of promoting the interest in contractual freedom while, at the same time, balancing the important need for minimum standards to protect legitimate expectations of fair and equitable conduct on the part of one's business partners. The contractarian model should acknowledge the need for and importance of such mandatory minimum standards to govern business relationships.

Regardless of how courts articulate their judicial tests, reverence for the written contract must be tempered with the recognition that judicial review is a good and essential thing, as is a mandatory core of acceptable manager and/or member conduct. It has been said that the "defining tension" in corporate governance today is the tension between deference to directors' decisions and the scope of judicial review. ${ }^{234}$ In this debate, I have suggested that the uncertainty of the law, and the corresponding specter of judicial intervention, are not unfortunate consequences to be avoided by the creation of a perfect statutory phrase or judicial test. Rather, judicial review is the healthy price and the all-important force that deters overreaching and enables the application of behavioral constraints within the context of our contractual scheme of self-governance. ${ }^{235}$ A broad approach to fiduciary duties is arguably preferable to a narrower test of entire fairness or a contractually oriented standard of good faith because it better reflects society's norms of ethical conduct, may be more effective in combating subtle freeze-out schemes, and does not rest on the assumption that the parties' relationship is governed by a highly negotiated and well-conceived contract.

that takes into account the perspectives of the parties, does not necessarily support the stronger party, and is more balanced than the law and economics efficiency principle).

${ }^{234}$ Veasey, supra note 217, at 403; see also Omnicare, Inc. v. NCS Healthcare, Inc., 818 A.2d 914, 928 (Del. 2003) (discussing the level of scrutiny to which managerial decisions are subjected before the business judgment rule is applied).

${ }^{235}$ Coffee, supra note 18 , at $1622-23$ ("Judicial activism is the necessary complement to contractual freedom."). 


\section{APPENDIX A}

\section{States with LLC Statutes}

\begin{tabular}{|c|c|}
\hline State & Statutory Provisions \\
\hline Alabama & ALA. CODE $\$ \S 10-12-1$ to -61 (1999 \& Supp. 2002) \\
\hline Alaska & ALASKA STAT. $\S \S 10.50 .010-.995$ (Michie 2002) \\
\hline Arizona & $\begin{array}{l}\text { ARIZ. REV. STAT. ANN. } \$ \$ 29-601 \text { to }-857 \text { (West } \\
1998 \text { \& Supp. 2003) }\end{array}$ \\
\hline Arkansas & $\begin{array}{l}\text { ARK CODE ANN. } \$ \S 4-32-101 \text { to }-401 \text { (Michie } 2001 \\
\text { \& Supp. 2003) }\end{array}$ \\
\hline California & $\begin{array}{l}\text { CAL. CORP. CODE } \$ \S 17,000-17,655 \text { (West Supp. } \\
2004 \text { ) }\end{array}$ \\
\hline Colorado & COLO. REV. STAT. $\$ \S 7-80-101$ to -1101 (2003) \\
\hline Connecticut & $\begin{array}{l}\text { CONN. GEN. STAT. ANN. } \$ \S 34-100 \text { to }-242 \text { (West } \\
1997 \text { \& Supp. 2003) }\end{array}$ \\
\hline Delaware & $\begin{array}{l}\text { DEL. CODE ANN. tit. } 6, \$ \S 18-101 \text { to }-1109 \text { (1999 \& } \\
\text { Supp. 2002) }\end{array}$ \\
\hline District of Columbia & $\begin{array}{l}\text { D.C. CODE ANN. } \$ \S 29-1001 \text { to }-1075 \text { (2001 \& } \\
\text { Supp. 2003) }\end{array}$ \\
\hline Florida & $\begin{array}{l}\text { FLA. STAT. ANN. } \$ \S 608.401-.705 \text { (West } 2001 \& \\
\text { Supp. 2004) }\end{array}$ \\
\hline Georgia & GA. CODE ANN. $\$ \$ 14-11-100$ to -1109 (2003) \\
\hline Hawaii & $\begin{array}{l}\text { HAW. REV. STAT. } \$ \$ 428-101 \text { to -1302 (Supp. } \\
\text { 2001) }\end{array}$ \\
\hline Idaho & $\begin{array}{l}\text { IDAHO CODE } \$ \S 53-601 \text { to }-672 \text { (Michie } 2000 \& \text { } \\
\text { Supp. 2003) }\end{array}$ \\
\hline Illinois & $\begin{array}{l}805 \text { ILL. COMP. STAT. ANN. 180/1-1 to } / 60-1 \\
\text { (West Supp. 2003) }\end{array}$ \\
\hline Indiana & $\begin{array}{l}\text { IND. CODE ANN. \$§ 23-18-1-1 to -13-1 (West } 1994 \\
\text { \& Supp. 2003) }\end{array}$ \\
\hline Iowa & $\begin{array}{l}\text { IOWA CODE ANN. } \S \S 490 \text { A.100-.1601 (West } 1999 \\
\text { \& Supp. 2003) }\end{array}$ \\
\hline Kansas & $\begin{array}{l}\text { KAN. STAT. ANN. } \$ \S 17-7663 \text { to }-76,142 \text { (Supp. } \\
\text { 2002) }\end{array}$ \\
\hline Kentucky & $\begin{array}{l}\text { KY. REV. STAT. ANN. } \$ \$ 275.001-.455 \text { (Michie } \\
\text { Supp. 2003) }\end{array}$ \\
\hline Louisiana & $\begin{array}{l}\text { LA. REV. STAT. ANN. } \$ \$ 12: 1301-: 1369 \text { (West } \\
1994 \text { \& Supp. 2004) }\end{array}$ \\
\hline Maine & $\begin{array}{l}\text { ME. REV. STAT. ANN. tit. 31, } \$ \S 601-762 \text { (West } \\
1996 \text { \& Supp. 2003) }\end{array}$ \\
\hline
\end{tabular}




\begin{tabular}{|c|c|}
\hline Maryland & $\begin{array}{l}\text { MD. CODE ANN., CORPS. \& ASS'NS } \S \S 4 \text { A-101 to - } \\
1103 \text { (1999 \& Supp. 2002) }\end{array}$ \\
\hline Massachusetts & $\begin{array}{l}\text { MASS. ANN. LAWS ch. 156C, } \$ \S 1-68 \text { (Law. Co-op. } \\
1996 \text { \& Supp. 2003) }\end{array}$ \\
\hline Michigan & $\begin{array}{l}\text { MICH. COMP. LAWS ANN. } \$ \$ 450.4101-.5200 \\
\text { (West } 2002 \& \text { Supp. 2003) }\end{array}$ \\
\hline Minnesota & $\begin{array}{l}\text { MINN. STAT. ANN. \$§ 322B.01-.960 (West } 1995 \& \text { } \\
\text { Supp. 2004) }\end{array}$ \\
\hline Mississippi & $\begin{array}{l}\text { Miss. CODE ANN. } \S \$ 79-29-101 \text { to }-1204 \text { (1999 \& } \\
\text { Supp. 2003) }\end{array}$ \\
\hline Missouri & $\begin{array}{l}\text { MO. ANN. STAT. } \$ \S 347.010-.740 \text { (West } 2001 \& \\
\text { Supp. 2003) }\end{array}$ \\
\hline Montana & MONT, CODE ANN. $\S \S 35-8-101$ to -1307 (2003) \\
\hline Nebraska & $\begin{array}{l}\text { NEB. REV. STAT. } \$ \S 21-2601 \text { to }-2653 \text { (1997 \& } \\
\text { Supp. 2003) }\end{array}$ \\
\hline Nevada & $\begin{array}{l}\text { NEV. REV. STAT. ANN. } \$ \$ 86.011-.590 \text { (Michie } \\
1999 \text { \& Supp. 2001) }\end{array}$ \\
\hline New Hampshire & $\begin{array}{l}\text { N.H. REV. STAT. ANN. } \$ \S 304-C: 1 \text { to }: 85 \text { (1995 \& } \\
\text { Supp. 2003) }\end{array}$ \\
\hline New Jersey & $\begin{array}{l}\text { N.J. STAT. ANN. } \$ \S 42: 2 B-1 \text { to }-70 \text { (West Supp. } \\
2003 \text { ) }\end{array}$ \\
\hline New Mexico & $\begin{array}{l}\text { N.M. STAT. ANN. } \S 53-19-1 \text { to }-74 \text { (Michie } 2001 \\
\text { \& Supp. 2003) }\end{array}$ \\
\hline New York & $\begin{array}{l}\text { N.Y. LTD. LIAB. CO. LAW } \$ \S 101-1403 \text { (McKinney } \\
2004 \text { ) }\end{array}$ \\
\hline North Carolina & N.C. GEN. STAT. $\$ \S 57 C-1-01$ to $-10-07$ (2003) \\
\hline North Dakota & $\begin{array}{l}\text { N.D. CENT. CODE } \S \S 10-32-01 \text { to }-156(2001 \& \\
\text { Supp. 2003) }\end{array}$ \\
\hline Ohio & $\begin{array}{l}\text { OHIO REV. CODE ANN. } \$ \S 1705.01-.58 \text { (Anderson } \\
2001 \text { \& Supp. 2002) }\end{array}$ \\
\hline Oklahoma & $\begin{array}{l}\text { OKLA. STAT. ANN. tit. 18, } \S \S 2000-2060 \text { (West } \\
1999 \text { \& Supp. 2004) }\end{array}$ \\
\hline Oregon & OR. REV. STAT. $\$ \$ 63.001-.990(2003)$ \\
\hline Pennsylvania & $\begin{array}{l}15 \text { PA. CONS. STAT. ANN. } \$ \S 8901-8998 \text { (West } \\
1995 \text { \& Supp. 2003) }\end{array}$ \\
\hline Rhode Island & $\begin{array}{l}\text { R.I. GEN. LAWS } \S \S 7-16-1 \text { to }-75 \text { (1999 \& Supp. } \\
\text { 2003) }\end{array}$ \\
\hline South Carolina & $\begin{array}{l}\text { S.C. CoDE ANN. } \S \S 33-44-101 \text { to -1207 (Law. Co- } \\
\text { op. Supp. 2003) }\end{array}$ \\
\hline South Dakota & $\begin{array}{l}\text { S.D. CoDIFIED LAWS } \$ \S 47-34-1 \text { to }-34 A-1207 \text { (Mi- } \\
\text { chie } 2000 \text { \& Supp. } 2003 \text { ) }\end{array}$ \\
\hline Tennessee & $\begin{array}{l}\text { TENN. CODE ANN. } \$ \S 48-201-101 \text { to }-248-606 \\
\text { (2002 \& Supp. 2003) }\end{array}$ \\
\hline Texas & $\begin{array}{l}\text { TEX. REV. CIV. STAT. ANN. art. 1528n, } \$ \S 1.01- \\
11.07 \text { (Vernon } 2003 \& \text { Supp. 2004) }\end{array}$ \\
\hline
\end{tabular}




\begin{tabular}{|c|c|}
\hline Utah & UTAH CODE ANN. $\S \S 48-2 c-101$ to -1902 (2002) \\
\hline Vermont & $\begin{array}{l}\text { VT. STAT. ANN. tit. 11, } \$ \$ 3001-3162(1997 \& \\
\text { Supp. 2003) }\end{array}$ \\
\hline Virginia & $\begin{array}{l}\text { VA. CODE ANN. } \$ \S 13.1-1000 \text { to }-1123 \text { (Michie } \\
1999 \text { \& Supp. 2003) }\end{array}$ \\
\hline Washington & $\begin{array}{l}\text { WASH. REV. CODE ANN. } \S \S 25.15 .005-.902 \text { (West } \\
\text { Supp. 2004) }\end{array}$ \\
\hline West Virginia & $\begin{array}{l}\text { W. VA. CODE ANN. } \$ 31 \mathrm{~B}-1-101 \text { to }-13-1306 \text { (Mi- } \\
\text { chie 2003) }\end{array}$ \\
\hline Wisconsin & $\begin{array}{l}\text { WIS. STAT. ANN. §§ 183.0102-.1305 (West } 2002 \& \\
\text { Supp. 2003) }\end{array}$ \\
\hline Wyoming & $\begin{array}{l}\text { WYO. STAT. ANN. } \$ \S 17-15-101 \text { to }-147 \text { (Michie } \\
\text { 2003) }\end{array}$ \\
\hline
\end{tabular}


APPENDIX B

\section{Table 1: LLC Statutes Using Good Faith Prudent Person Language*}

\begin{tabular}{|c|c|}
\hline State & Statutory Provision \\
\hline Alaska & ALASKA STAT. $\$ 10.50 .135$ (a) (Michie 2002) \\
\hline Colorado & COLO. REV. STAT. $\$ 7-80-406$ (a) (2003) \\
\hline Connecticut & CONN. GEN. STAT. ANN. § 34-141 (a) (West 1997) \\
\hline Georgia & GA. CODE ANN. $\S 14-11-305(1)(2003)$ \\
\hline Iowa & IOWA CODE ANN. § 490A.706(1) (West 1999) \\
\hline Louisiana & $\begin{array}{l}\text { LA. REV. STAT. ANN. \& 12:1314(A)(1) (West } 1994 \\
\text { \& Supp. 2004) }\end{array}$ \\
\hline Maine & ME. REv. STAT. ANN. tit. 31, $\$ 652(1)$ (West 1996) \\
\hline Michigan & $\begin{array}{l}\text { MICH. COMP. LAWS ANN. } \$ 450.4404 \text { (1) (West } \\
\text { 2002) }\end{array}$ \\
\hline Minnesota & MINN. STAT. ANN. $\$ 322 B .69$ (West 1995) \\
\hline Mississippi & MISS. CODE ANN. \$ 79-29-402(1) (1999) \\
\hline Missouri & MO. ANN. STAT. $\S 347.088(1)$ (West 2001) \\
\hline New York & $\begin{array}{l}\text { N.Y. LTD. LIAB. CO. LAW } \$ 409 \text { (a) (McKinney } \\
\text { 2004) }\end{array}$ \\
\hline North Carolina & N.C. GEN. STAT. \$ 57C-3-22(b) (2003) \\
\hline North Dakota & $\begin{array}{l}\text { N.D. CENT. CODE } \$ 10-32-96 \text { (2001 \& Supp. } \\
\text { 2003) }\end{array}$ \\
\hline Ohio & $\begin{array}{l}\text { OHIO REV. CODE ANN. } \$ 1705.29 \text { (B) (Anderson } \\
\text { 2001) }\end{array}$ \\
\hline Oklahoma & $\begin{array}{l}\text { OKLA. STAT. ANN. tit. 18, } \$ 2016(1) \text { (West } 1999 \& \\
\text { Supp. 2004) }\end{array}$ \\
\hline Pennsylvania & $\begin{array}{l}15 \text { PA. CONS. STAT. ANN. } \$ \S 8943,1712 \text { (a) (West } \\
1995 \text { \& Supp. 2003) }\end{array}$ \\
\hline
\end{tabular}

* The actual language employed varies from statute to statute. For comprehensive tables, discussion, and analysis of duty of care and duty of loyalty provisions, see BISHOP \& KLEINBERGER, supra note 7, II 10-16; RIBSTEIN \& KEATINGE, supra note 7, app. 9-1. 


\begin{tabular}{|l|l|}
\hline Rhode Island & R.I. GEN. LAWS § 7-16-17(a) (1999) \\
\hline Tennessee & $\begin{array}{l}\text { TENN. CODE ANN. \$ } \\
(2002)\end{array}$ \\
\hline Vermont & VT. STAT. ANN. tit. 11, §3059(c) (1997) \\
\hline Virginia & VA. CODE ANN. § 13.1-1024.1 (Michie 1999) \\
\hline
\end{tabular}

\section{Table 2: LLC. Statutes Using Gross Negligence or Willful Misconduct Language}

\begin{tabular}{|c|c|}
\hline State & Statutory Provisions \\
\hline Alabama & ALA. CODE $\S 10-12-21(\mathrm{~g}),(\mathrm{k})(2)$ (1999) \\
\hline Arkansas & $\begin{array}{l}\text { ARK. CODE ANN. } \S 4-32-402 \text { (Michie } 2001 \& \\
\text { Supp. 2003) }\end{array}$ \\
\hline California & CAL. CORP. CODE $\$ 17,153$ (West Supp. 2004) \\
\hline District of Columbia & D.C. CODE ANN. \$ 29-1003 (2001) \\
\hline Florida & $\begin{array}{l}\text { FLA. STAT. ANN. } \S 608.4225 \text { (1) (b) (West } 2001 \& \text { } \\
\text { Supp. 2004) }\end{array}$ \\
\hline Hawaii & HAW. REV. STAT. $\$ 428-409$ (c) (Supp. 2001) \\
\hline Idaho & IDAHO CODE $\$$ 53-622(1) (Michie 2000) \\
\hline Illinois & $\begin{array}{l}805 \text { ILL. COMP. STAT. ANN. 180/15-3 (West Supp. } \\
\text { 2003) }\end{array}$ \\
\hline Indiana & IND. CODE ANN. § 23-18-4-2 (West 1994) \\
\hline Kentucky & $\begin{array}{l}\text { KY. REV. STAT. ANN. } \$ 275.170(1) \text { (Michie Supp. } \\
\text { 2003) }\end{array}$ \\
\hline Montana & MONT. CODE ANN. § 35-8-310(3) (2003) \\
\hline New Hampshire & N.H. REV. STAT. ANN. § 304-C:31(IV) (1995) \\
\hline New Mexico & N.M. STAT. ANN. \$ 53-19-16(B) (Michie 2001) \\
\hline Oregon & OR. REV. STAT. § 63.155(3) (2003) \\
\hline South Carolina & $\begin{array}{l}\text { S.C. CODE ANN. \$ 33-44-101 to -1207 (Law. Co- } \\
\text { op. Supp. 2003) }\end{array}$ \\
\hline
\end{tabular}




\begin{tabular}{|l|l|}
\hline Utah & UTAH CODE ANN. § 48-2c-807(1) (2002) \\
\hline Washington & $\begin{array}{l}\text { WASH. REV. CODE ANN. § 25.15.155(1) (West } \\
\text { Supp. 2004) }\end{array}$ \\
\hline West Virginia & W. VA. CODE ANN. § 31B-4-409(c) (Michie 2003) \\
\hline Wisconsin & WIS. STAT. ANN. \$ 183.0402(1) (West 2002) \\
\hline
\end{tabular}

